\title{
A COMPARISON OF TWO METHODS OF TEACHING \\ LISTENING COMPREHENSION \\ TO COLLEGE FRESHMEN
}

\author{
By \\ THOMAS L. COTTRILL \\ Bachelor of Arts \\ Northeastern State College \\ Tahlequah, Oklahoma \\ 1965 \\ Master of Teaching \\ Northeastern State College \\ Tahlequah, Oklahoma \\ 1967
}

Submitted to the Faculty of the Graduate College of the Oklahoma State University

in partial fulfillment of the requirements

for the Degree of

DOCTOR OF EDUCATION

July, 1972 
A COMPARISON OF TWO METHODS OF TEACHING

LISTENING COMPREHENSION

TO COLLEGE FRESHMEN

Thesis Approved:
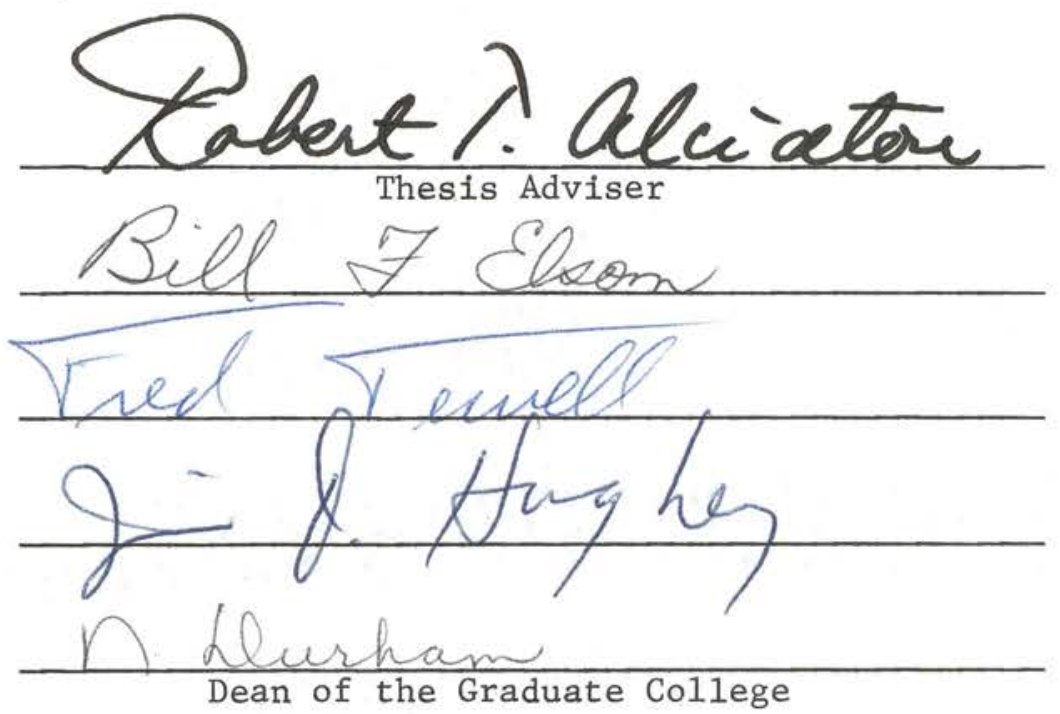

Dean of the Graduate College 


\section{ACKNOWLEDGEMENTS}

The work reported in this investigation was performed in the Division of Communications at Northeastern State College, Tahlequah, Oklahoma. The major objective of this study was to compare the effectiveness of two methods of teaching 11stening comprehension to college freshmen. It is hoped that the endeavors of this study will provide a basis for further investigation in this area.

I am especially grateful to Dr. Robert T. Alciatore, chairman of the doctoral committee, for his assistance, encouragement, and generous investment of time. I would further like to express my appreciation to Dr. Bill E1som, Dr. Jim Hughey, and Dr. Fred Tewe11, who so willingly served on the doctoral committee.

Gratitude is expressed to Northeastern State College for the sabbatical leave-of-absence which made the completion of this program and study possible. A note of thanks is also extended to those faculty members and students of the Northeastern speech department without whose cooperation there would have been no study. I wish to extend special appreciation to Dr. Valgene Littlefield, Professor of Speech at Northeastern State College, whose masterful teaching is responsible for generating my interest in listening comprehension.

I extend great thanks to my parents, George and Jane Striplin, whose lifetime of encouragement and direction I am fortunate to have. Finally, I am eternally indebted to my wife, Anne, and my daughter, Debbie, who sacrificed the most in order that this study might be made. 


\section{TABLE OF CONTENTS}

Chapter

Page

I. INTRODUCTION . . . . . . . . . . . . . . . . . 1

Statement of the Problem and Hypotheses ....... 5

Definition of Terms . . . . . . . . . . . 6

Assumptions . . . . . . . . . . . . . 7

Limitations of the Study . . . . . . . . . 8

Significance of the Study . . . . . . . . . . 8

Reporting the Study . . . . . . . . . . . 9

Summary . . . . . . . . . . . . . . . 9

II. REVIEW OF THE LITERATURE 11

What is Listening? . . . . . . . . . . . . 12

The Importance of Listening . . . . . . . . . . 15

Teaching Listening Comprehension . . . . . . . . 21

Summary . . . . . . . . . . . . . . 28

III. DESIGN AND METHODOLOGY . . . . . . . . . . . . 30

Introduction . . . . . . . . . . . . 30

Research Design and Procedure . . . . . . . . 31

Population and Sample............. . 34

The Programmed Materials . . . . . . . . . 34

The Measuring Instruments . . . . . . . . . 37

The Statistical Treatment . . . . . . . . 39

Summary . . . . . . . . . . . . . . 40

IV. REPORTING THE STUDY . . . . . . . . . . . . . 41

Description of Data and Testing of Hypotheses . . . 43

Analysis of Questionnaires Relative to Method

of Instruction... . . . . . . . . . . 59

Summary .................. 62

V. SUMMARY, CONCLUSIONS, AND RECOMMENDATIONS . . . . . . 63

General Summary of the Investigation . . . . . . 63

Conclusions of the Study . . . . . . . . . . 65

Recommendations for Further Research .. . . . . 67

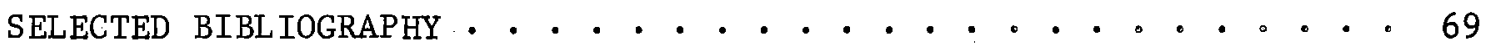

APPENDIX - INSTRUCTIONAL ATTITUDE QUESTIONNAIRE • • • • • • • 76 
Table

Page

I. Distribution of Students by Classes............ 43

II. Analysis of Variance of Method of Teaching Listening Comprehension and Time of Day Instruction Was Received (Composite Score). . . . . .

III. Analysis of Variance of Method of. Teaching Listening Comprehension and Tice of Day Instruction Was Received (Immediate Reca11) . . . . . . 50

IV. Analysis of Variance of Method of Teaching Listening Comprehension and Time of Day Instruction Was Recelved (Following Directions) . . . . . 52

V. Analysis of Variance of Method of Teaching Listening Comprehension and Time of Day Instruction Was Received (Recognizing Transitions). . . . 54

VI. Analysis of Variance of Method of Teaching Listening Comprehension and Time of Day Instruction Was Received (Word Meanings). . . . . . . 56

VII. Analysis of Variance of Method of Teaching Listening Comprehension and Time of Day Instruction Was Received (Lecture Comprehension). . . . 58

VIII. Average Questionnaire Response Toward Instructional Method Received . . . . . . . . 60

IX. Frequency Response of Attitude Intensity . . . . . . . . 61 
CHAPTER I

INTRODUCTION

Perhaps no aspect of the human experience is more clearly requisite to survival than relationships with other people. Man learns early in his existence that others can help satisfy his needs and wants if he can only make them known. The child discovers that certain sounds or actions will result in subsequent actions or reactions from others. Eventually, through the imitative and educative process, the child learns that he can make his ideas readily known, and thus more accurately control or predict the reactions of others, if he uses certain symbols in particular patterns. It is certainly here, if not before, that the advantages and importance of communication become apparent to the communicator.

In its broadest interpretation, interpersonal communication is the sharing of ideas and feelings. This transfer takes place through a system of symbols which may range a11 the way from spoken and written words to musical sounds, colors, designs, and motions. Most agree that the objective of the communicative act is to elicit a desired response from a recipient. The degree of success derived from the communication act depends upon the extent of the agreement between expressor and receptor as to the meaning of the symbols used. Effective communication, then, seeks to promote a common understanding which is a prerequisite to success in most endeavors. 
Verbal communication is generally perceived as involving four primary activities: reading, writing, speaking, and listening. A study by Paul T. Rankin (1) points out that the average individual devotes approximately 70 per cent of his waking hours to communication. Specifically, Rankin discovered that 16 per cent is spent writing, 30 per cent is spent talking, and 45 per cent is spent listening. Thus, almost half of our communicative time is devoted to the act of listening. Today, as never before, sounds and voices clamor for our attention. Listening is a fundamental pretept of our lives and, as such, is basic to success in school and business alike. People need to be able to disregard other interests in order to concentrate on meaningful sounds. The population is bombarded by a plethora of sounds often before it develops the powers to discriminate between what is meaningful and useful and what is not. With today's rapid dissemination of information, efficient listening and alert minds are needed to discriminate between fact and inference, truth and almost-truth.

If one momentarily reflects upon his academic preparation to assume his "average" communicative role, he no doubt easily remembers his earliest encounters with the "reading circle" and the emphasis placed on becoming a proficient reader. He may remember the pains of learning to print and then moving on to the construction of ovals and eventually cursive writing. He may remember his teachers' concern with his pronunciation, or he might even have taken a speech course where considerably more emphasis was placed on his speech and speaking ability. But how many can recall ever receiving structured, meaningful instruction for the purpose of improving the skill of listening? Unfortunately, the extent of listening instruction has too often been 
a series of admonitions such as "Listen to this!," "This is important, 1isten:," or "Sit down, shut up, and 1isten!" It appears that the majority of our communicative time is devoted to employing a "skill" in which we have had the least training. If the magnitude of this reali-a. zation were not bad enough, recent research now tells us that the elementary student spends about 50 per cent of his time listening, the high school student 80 per cent, and the college student $90+$ per cent. Despite the amount of time which one devotes to listening, it can not be concluded that the time is necessarily spent wisely. In order to substantiate this, one has only to remember the times he has been asked to repeat statements just made, or repeat directions two or three times. The average person's inability to retain a phone number for any length of time is further evidence of the problem. Ralph G. Nichols (2) found that the average person will retain only 50 per cent of what he hears, regardless of how hard he concentrates, and that two months later he will retain only half of that amount. Stanford Taylor (3) concludes that this condition is not surprising when one considers the negligible amount of instruction provided in listening, the lack of a sequential developmental listening program in most schools, and the inherent complexity of the listening act.

Perhaps the major task which educators have had to face regarding the improvement of listening skills is the decision as to which, if any, method works best. Not all authorities are in agreement regarding the viability of the teachability of listening skills. Herbert Hackett (4) contends that there is no evidence that listening instruction is more than a current fad, or that knowledge about listening contributes to the ability to listen. Paul Bakan (5) questions five assumptions 
upon which he feels that listening instruction is based:

1. listening is a single skill;

2. 1istening training should be given to all students;

3. listening is teachable;

4. listening is an independent skill;

5. listening can be effectively evaluated.

While these contentions represent a minority viewpoint, they are nevertheless authoritative conclusions.

The "traditional" listening instruction method, as has been pointed out, does not appear to have filled the void. Telling pupils something they should know is not, as teachers know, synonymous with their learning it. The major techniques employed up to the present have included direct instruction, indirect instruction, integrative instruction, the eclectic approach, the "games" approach, a "skills" approach, and others. While all of the approaches seem to yield slight success, they nevertheless fall short of the proficiency output hoped for by most researchers.

The pedagogical approach which is the most recent and, as of yet, least employed is that of the programmed approach to listening improvement. With the exception of a study by Barker and Wiseman (6) and one by Binder and McGlone ( 7 ), studies up to this point do not appear to have investigated the merits of a programmed approach for the development of listening skills. Thus, the problem of how best to teach listening comprehension skills remains, and the question of whether a programmed instructional method can serve as an effective means of teaching listening comprehension seems imminent.

Through the present study the investigator will attempt to deter- 
mine the effectiveness of two methods of teaching listening comprehension. This will be achieved by comparing the listening achievement scores of subjects taught by a programmed approach with those taught by the conventional approach in the basic speech course at Northeastern State College. The group approach to the use of the programmed materials will be used as opposed to each student working the program at his own rate. The duration of the instructional program will be two weeks or six class sessions.

Statement of the Problem and Hypotheses

The purpose of this study is threefold: to ascertain if there is a significant difference between the listening achievement scores of students taught by a programmed approach and those taught by a conventional approach; to discover if time of day the instruction is received has any bearing on the listening achievement scores of either approach; and to ascertain students' attitudes toward the programmed approach and conventional approach to listening instruction. The structure of this investigation is designed to focus on the central issue; Can programmed instruction serve as an effective means of teaching listening comprehension to college freshmen enrolled in Speech 113, "Ora1 Communication," at Northeastern State College?

The dependent variable in this study is the achievement score on the Brown-Carlsen Listening Comprehension Test. The two independent variables in the investigation are method of listening instruction and the time of day at which the instruction is received.

In an attempt to arrive at a solution to the problem the following cluster hypotheses were formulated and will be evaluated at the .05 
leve1 of significance:

I. There is no significant difference in the 1istening achievement scores of freshmen enrolled in Speech 113 at Northeastern State College due to the use of programmed 1istening instruction as opposed to the conventional method of instruction.

II. There is no significant difference in the listening achievement scores of freshmen: enrolled in Speech 113 at Northeastern State College due to the time of day listening instruction is received.

III. There is no significant difference in the 1istening achievement scores of freshmen enrolled in Speech 113 at Northeastern State College due to the interaction of method of listening instruction and time of day instruction is received.

IV. There is no significant difference in the listening achievement scores of freshmen enrolled in Speech 113 at Northeastern State College due to the method of 1istening instruction received, time of day the instruction is received, or the interaction of method and time of day relative to:

A. Listening for immediate recall.

B. Listening to follow directions.

C. Listening to recognize transitions.

D. Listening to recognize word meanings.

E. Listening for lecture comprehension.

$$
\text { Definition of Terms }
$$

Hearing is the mere physiological process of being exposed to sound waves whereby they enter the ear but have no particular meaning 
associated with them.

Listening means the ability of a person to receive and retain oral language so as to affix meaning and comprehension to those symbols which are heard.

Comprehension is evidence of understanding that which is heard by making appropriate written or oral responses to the verbal stimulus. Listening Achievement refers to the score made on form BM of the Brown-Carlsen Listening Comprehension Test.

Conventional instructional approach is the teaching technique which employs lecture, class discussion, and assigned reading in both the text and selected supplementary sources.

Programmed instructional approach is the use of the Xerox Effective Listening programmed approach to listening improvement.

Frame is a unit of the listening program which requires a subject to respond.

Attitude toward approach means the subjects' feelings concerning the instructional method they received as indicated by their responses on the attitude questionnaire.

Control group refers to those individuals who received the conventional method of listening instruction.

Experimental group refers to those individuals who received the programmed approach to listening improvement.

Freshmen include students enrolled at Northeastern State College who have 30 or fewer semester hours of college credit on record.

Assumptions

Two basic assumptions underlie the framework of this investigation: 
1. The instructors involved in the study will teach in the assigned manner.

2. The effectiveness of the method of instruction can be determined by the measuring instrument employed.

Other aspects relevant to the execution of this study will be coordinated by the investigator to ensure maximum effectiveness. Great care will be taken to see that the subjects are not aware of their role in the experiment in an attempt to negate the "Hawthorne" effect. The homogeneity of the sample will be determined by use of a heterogeneity check. Each instructor in the study will be thoroughly briefed on the use of equipment. necessary for the study. The instructor will not present a variable significant to invalidate the study since six different instructors were randomly assigned to teach the classes under investigation.

\section{Limitations of the Study}

The study will be restricted to freshmen enrolled in the six experimental sections of Speech 113 at Northeastern State College during the spring semester of 1972 .

\section{Significance of the Study}

While improvement comes through a willingness to employ new and different techniques, one should avoid change merely for the sake of change. Before stringently adhering to a new approach for the instruction and development of any skill, one should assure himself that the new approach is indeed superior to the conventional one. The significance of the present study lies in the fact that it should reveal the 
effects of using a programmed approach to teaching listening comprehension to college freshmen in the basic speech course at Northeastern State College.

\section{Reporting the Study}

This study is designed to determine the better of two methods for teaching listening comprehension to college freshmen. Two groups of subjects, control and experimental, will recelve instruction in listening skills by two different methods: conventional and programmed. The listening achievement of the subjects will be analyzed statistically.

Chapter II contains a review of the literature on the nature of 1istening, the importance of listening, and the teaching of listening comprehension skills.

Chpater III discusses the research design and methodology which was utilized, the measuring instruments used, and the statistical treatment which was employed.

Chapter IV presents the results and findings of the investigation including the statistical outcomes based on the information secured from the measurement instruments。

Chapter $V$ summarizes the major findings of the study, presents conclusions, and makes recommendations for further research in this area.

\section{Summary}

This chapter has been concerned with the importance of communication in general and the skill of listening in particular. The element of major concern is that, ias Nichols (2) and Taylor (3) point out, so 
much time is spent engaged in a communicative activity for which so little proficiency is exhibited. Past educational practices of teaching the skill of listening have been cast in a questionable light. While some other pedagogical practices for teaching listening comprehension have been tried, one which seems to hold a great deal of promise is the use of programmed instruction. This writer has attempted to establish a rationale, limitations, assumptions, significance, and hypotheses which would lend credibility and support for a study of programmed instruction as a means of teaching listening comprehension to college freshmen. 


\section{CHAPTER II}

\section{REVIEW OF THE LITERATURE}

Few areas of communication have received a greater degree of research emphasis in the last twenty years than has that of 1istening comprehension. As Taylor (3) notes, 90 per cent of listening research has been conducted since 1952. The expanse of material on 1istening since 1950 has led Sam Duker, professor of education at Brooklyn College (8), to conclude that we know a great deal about 1 istening, so much so that "1istening skil1 and listening performance can and have been improved by instruction." But the very same material has caused Charles Petrie, professor of speech at Buffalo University (8), to conclude that while we do know much about listening, we do not know enough about how to improve that ability. Regardless of the side which one chooses to support, most agree that listening is an important and integral part of human communication and interaction; consequently, any knowledge of how to modify that skill is invaluable.

Those interested in the teaching of listening are in a quandary-should it be taught directly, as an isolated, separate area of knowledge, or should it be taught indirectly; as a part of the materials ordinarily taught in the communications course? Solutions to the predicament might be generated by reviewing some of the major studies and articles which have been written in an attempt to confront this dilemma. Suggestions included in these concern: (1) what listening is, (2) the 
importance of the skill of listening, and (3) the teaching of listening comprehension skills. Since the major concern of the present investigation is with the acquisition and utilization of listening skills, the teaching of listening comprehension will be given primary emphasis in this review.

What Is Lịstening?

Most authorities agree that listening is more than the mere perception of a sound. Taylor (3), for instance, uses the term hearing to designate the process by which speech sounds in the form of sound waves are received and modified in the ear, while listening refers to the process of becoming aware of sound sequences. More specifically Taylor contends that the factors which influence hearing differ from those which affect listening. Hearing is influenced by the factors of auditory acuity, masking, auditory fatigue, and binaural considerations; listening is influenced by attention and concentration, auditory analysis, mental reorganization, association of meaning, and rate of input. Barbara (9) feels that successful listening presupposes hearing and precedes understanding. Fulton (10) concludes that the distinction between hearing and listening must be stressed if the learner is to become a perceptive auditor.

Beyond this point, however, solid agreement or unanimity as to what occurs is difficult to isolate. One reason for this difficulty is that varying degrees of emphasis are placed on the constituents of 1istening. As Petrie (11) notes, this does not mean that any one view is correct and the others wrong, but rather the authorities may be viewing the process from different angles or points of view. 
A contribution to this problem is the communicative concept of "process." Berlo's (12) concept of process is "the belief that the structure of physical reality cannot be discovered by mas it must be created by man." He further argues that if we accept the concept of process, we must view events and relationships as dynamic, on-going, and continuous. Hence, to label something as a process one must mean that it does not have a fixed beginning or a fixed end in a structured sequence of events. The ingredients within a process interact with each element affecting all of the others. Nevertheless, the result of these differences has been some differing definitions as to what listening actually is. Paul Bakan (5) contends that:

. . workers in the field of listening are guided in their thinking by implicit assumptions which may tend to oversimplify the problem. It is felt that current attempts to establish programs to teach listening skills suffer from a serious lack of basic information about listening behavior. In order to teach listening skills effectively more information about the nature of listening is required.

It is not surprising, then, that it is difficult to establish a definition of listening upon which most persons will agree. While there is disagreement concerning the elements and processes encompassed by the term, there is similar disagreement in attempting to isolate the factors involved in the process of 11stening. Some representative definitions include the following:

- . the complete process by which oral language communicated by some source is received, critically and purposefully attended to, recognized and interpreted in terms of past experiences and future expectancies--Petrie (11)

- . an analysis of the impressions resulting from concentration where an effort of will is required Tucker (13)

- . the capacity of an individual to understand spoken language in the presence of a speaker--Still (14) 
- . the attachment of meaning to oral symbols-Nichols (15)

- . a selective process by which sounds communicated by some source are received, critically interpreted, and acted upon by a purposeful listener--Jones (16)

- . comprising both receptive and reflective Iistening

- - reception. . in terms of (1) getting lecture

details, (2) following oral directions, and (3) keeping

a sequence of details in mind. Reflective, or critical, listening. . . in terms of (1) getting central ideas, (2) drawing inferences, (3) distinguishing relevant from irrelevant material, (4) using contextual clues to determine word meaning, and (5) identifying transitional elements--Brown-Carlsen (17)

- . a definite, usually voluntary, effort to apprehend accoustically--Barbara (9)

- . understanding spoken language--Rankin (18)

- . the process of reacting to, interpreting, and relating the spoken language in terms of past experiences and future courses of action--Barbe and Myers (19)

- . the selective process of attending to, hearing, understanding, and remembering aural symbols--Barker (20)

These definitions differ in a number of ways. Some suggest that the symbols must be verbal while others include non-verbal symbols such as the ringing of bells and the closing of doors. Some definitions specify a face-to-face relationship while others include the uniqueness of mass media. Some isolate the listening aspect of communication while others view listening as an interrelated process inseparable from oral communication in general.

Some authorities, Brown (21) and Caffrey (22), finding dissatisfaction with the incompleteness of the term listening, have coined a new expression which purports not only to be more inclusive but more descriptive. Brown (21) defines the term "auding" as "The process of listening to, reorganizing, and interpreting spoken symbols." Taylor 
(3) supports the use of the term "auding" by seeing it as the extension or ultimate of listening. He argues that as each word is recognized, it is added to, and becomes a part of the spoken message. Consequently, as the listener assimilates the flow of words he must respond with some understanding or feeling--or "aud." Commenting on the uniqueness of auding, Taylor differentiates its influencing factors as follows: (1) indexing, (2) making comparison, (3) noting sequence, (4) forming sensory impressions, and (5) appreciating. While Petrie (11) agrees with the use of the term "aud," he verbalizes this writer's sentiments when he points out that while auding may be a more precise term, one cannot ignore the fact that the term listening has been fully established in our culture and is therefore difficult to depose.

The Importance of Listening

The importance of 1istening can be gleaned from an examination of the quantity of time devoted to listening, its maturational and educational aspects, its relationship to other language arts, and its relationship to the learning process.

In 1926 Rankin (23) made his noted study which found that the average person spends approximately 70 per cent of his waking hours engaged in some form of communication. Of this wakened period of one's day he found that 9 per cent was devoted to writing, 16 per cent to reading, 30 per cent to speaking, and 45 per cent to listening. The study has been replicated by Breiter (24) who conducted the study among housewives and Bird (25) who ran the same study of 110 dieticians and achieved the same basic results. On the basis of a 1956 study, Richard Hubbell (26) concluded that 98 per cent of all we learn in a lifetime 
is through our eyes or ears. In a study designed to ascertain the distribution of communicative time of elementary students, Wilt (27) asked elementary teachers to estimate the amount of time they thought their students spent listening to them in the classroom. These estimates were then compared with the actual time the students spent listening in their class. The results showed that the students spent better than twice as much time listening to the teachers as the teachers had estimated (77 minutes estimated and 158 minutes actual). Hence approximately 55 per cent of the elementary students' time is spent listening to the teacher. A study by Bruce Markgraf (28) revealed that a high school student spends approximately 46 per cent of his school day listening and 66 per cent of that time is spent listening to the teacher. Estimates of the amount of time a college student devotes to listening in the classroom are approximately 90 per cent. Appell and Appe11 (29) conclude that "the teacher who 1istens, creates an atmosphere which encourages appreciation for the development of listening skills."

The maturational and educational aspect of communicative usage further depicts the importance of listening skills. In a study by Taylor, Frackenpoh1, and Pettee (30) they found that 1istening ability surpassed reading ability for children of average intelligence and scholastic ability in the primary and intermediate grades (1-6). These children preferred to listen rather than read when given a choice. They concluded that the reason for this preference was because listening was the more "usual" act to which students were accustomed, whereas reading was more difficult because of work comprehension and recognition rate. It was not until grade 6.5-7.0 that reading proficiency 
seemed to gain the efficiency to become the preferred act in most learning situations. They further discovered that even at this point, listening was preferred when the material was easy and reading was selected when the material was judged to be difficult. The writers concluded that this is probably due to the fact that the learner is able to set his own pace in reading, whereas the speaker sets the communicative pace in oral communication. Closely aligned with the Taylor results, Erickson and King (31) found oral presentation to be more effective in grades below the efghth and reading more effective in the grades following.

Thus, it would appear that listening, as the primary or preferential communicative skill, ceases development and assumes an adjunct if not subordinate role to reading at about the seventh grade. Perhaps this realization would not be as important were it not that while one ceases to develop his listening skill, he nevertheless continues to depend upon it for approximately 50 per cent of the communication in which he engages for the rest of his 1ife. Additionally, 1istening skills take a backseat to reading at a point when less than one-half of a person's formal education is complete and the remaining educational experiences, certainly college, will necessitate that he rely on his listening ability almost twice as much as he had up to this point. Complementing this dilemma is the realization that in his later educational experiences the student will probably receive less training in listening than he has his first six years of school.

The relationship of 1 istening to the other language arts provides additional Impetus for concern. Beery (32) points out that all of the other language arts skills, speaking, writing, and reading are learned 
through 1istening. In reality, 1istening is the first language arts skill in which one engages. Corroboration of this point is finalized, it would seem, in that no language known to man has ever been written before it was spoken. In further substantiation of the relationship between 1 istening and the other language arts skills, Canfield (33) used 149 subjects in a study where the correlation between listening ability and reading ability was found to be .60 , and .74 between 1 istening and school grades. Erickson (34), in a well-designed and executed study of 309 college students given twelve weeks of systematic listening instruction found correlations with listening of .67 with reading ability, .77 with intelligence, and .67 with vocabulary. Numerous other studies, Bonner (35), Haugh (36), Hollow (37), Marsden (38), and Vineyard and Balley (39), substantiate the relationship of listening to the other language arts. While one would be remiss to imp1y that a11 correlative studies demonstrated a positive relationship between listening and reading, the majority of them do report such. No attempt has been made here to relate the teaching methodology of listening in conjunction with other language skills; that will follow in a later discussion of teaching approaches.

- Another relationship supportive of the importance of listening involves the process of learning. Hayward (40) emphasizes the importance of training in listening in the improvement of learning. Berlo (12) feels that listening and learning overlap, while Dance (41) argues that the total process of communication, including listening, is synonymous with the learning process. Heilman (42), however, contends that there are "numerous questions which must be answered before 1istening can be held synonymous with learning." It is important to note that 
even Heilman's questions do not negate the position that listening can contribute to effective learning. Nichols and Stevens (2) refer to listening as "the missing ' $L$ ' in learning." Studies by Hampleman (43), Henmon (44), and Witty and Sizemore (45) all point to the important relationship which exists between listening and learning and provide numerous suggestions to nurture this relation for optimum cesults.

As noted earlier in this chapter, listening presupposes hearing. That is, before listening can occur there must first be a sound or series of sounds which are audible to the listener. Fulfilling this prerequisite, listening, as herein operationally defined, then begins. Fessenden (46) theorized that listening actually develops in a series of leve1s, much as learning:

1. Isolation of sounds.

2. Identification of meaning.

3. Integration with past experiences.

4. Inspection of its impact on one's ideas.

5. Interpretation of the impact.

6. Interpolation of one's own ideas.

7. Introspection.

If one adheres to the process which Fessenden purports, listening is a series of levels and the efficiency with which one listens is dependent upon how many of the levels he can successfully employ. Thus, a problem at any one of the levels may indeed magnify itself in one's attempt to reach the next level. This could possibly account for one's getting "half-meanings" or "partially misunderstanding" what has been heard.

Stanford Taylor (3) seems to be in close agreement with Fessenden 
in terms of the developmental aspects of listening, except that he prefers to envision it in a somewhat more concise manner. As he states, "While the total act of receiving auditory communication is generally referred to as 'listening,' it may be clearer to think of this act in three distinguishable states: hearing, listening, and auding." For Taylor, hearing encompasses Fessenden's first level; listening represents levels two through five; and auding includes levels six and seven. Barker (20) disagrammatically analyzes the development of the listening process, including many of the same precepts already discussed. While 11stening is important in the classroom, its function is by no means confined to a classroom. Business and industry have a very real interest in employees' ability to 1isten. Nichols (47) found that the average white collar worker spends approximately 45 per cent of his workday listening and consequently one-half of his salary is earned based on his ability to 1isten. An interesting aspect of Nichols' findings was that this same employee exhibits only 50 per cent efficiency at the task. Commenting on this problem, Drucker (48) states that listening ability needs to be developed by top and middle management, and by workers in industrial situations if communications are to be effective. Analyzing the industrial listening problem from an economic viewpoint, Dover (49) feels "It is reasonable to suppose that deficlencies in listening skills cause business and industry to lose millions of dollars annually." Upon completion of a survey of the communicative structure of his company, Caskey (50) concluded that "Efficient listening is essential to success as an industrial supervisor and certainly so in any other aspect of the business community." Perhaps the role of listening in business is best summed up by Frank 
E. Fischer (51), director of the Communications Course of the American Management Association, who declares, "Efficient listening is of such critical importance to industry, that as research and methodology improve I feel that training departments will have to offer courses in this field."

Unfortunately, the amount of time an individual devotes to listening is not indicative of his ability to perform the skill. Perhaps the first to reveal this inconsistency was Professor Harry Jones (52) in a study conducted in 1923. Jones had fifty professors each give a ten mintute cutting of his favorite lecture to a psychology class of 476 students. After each talk the class was given an objective test over its content. Jones found that on the average the class could answer only 50 per cent of the items. Two months later Jones brought the class together again and readministered the fifty tests. This time the subjects were able to recall only 25 per cent of the information. This study was replicated by Nichols (47), but rather than waiting two months for the retest, he administered it in only two weeks. His results corroborated the outcome of the Jones study. An analysis of certain aspects of the Michigan State University 1istening training program conducted by Irvin (53) yielded similar results. The prospect of a 25 per cent efficiency level in any "skill" is in itself a less than desirable prognosis, but it becomes more so when one remembers that almost 50 per cent of a person's communicative time is devoted to this ski11.

Teaching Listening Comprehension

While there has been a growing awareness of the importance of 
listening skills, there has also been increased interest in the teaching of listening. Applegate (54) insists, "It is erroneous to assume that a child will either listen well or not. The child is entitled to be trained in this skill." Anderson (55) insists that "Since listening is the most used language arts skill, the school should teach it. Teachers have a responsibility to teach it, learn it, and practice it." Studies and exhaustive investigations by numerous authorities, Nichols (56), Dow and Irvin (57), and Cashman (58), leave relatively 1ittle doubt as to the teachability of listening skills. It shoild be noted, however, that the field is by no means in total agreement. Paul Bakan (5) argues that successful attempts to teach listening comprehension suffer from a serious lack of basic information about listening behavior itself. An equally intensive volce of doubt is that of Herbert Hackett (4). He insists that there is no evidence that knowledge about listening contributes to the ability to listen. Hackett further insists :

- . Most of our instruction is of the 'hoo-rah' or as John Caffrey says, 'the chatsy-patsy lend-me-your-ears, folks,' variety; much of this instruction consists of 'Listen, damn it!' 'No wonder,' he continues, 'so much of our communications research. . . is either regurgitative or soothingly and unarguably paltitudinous.'

But, as is the case with most who assault constructive attempts, Hackett is forced to admit, "It is far easier to defend my null hypothesis, that there is not sufficient evidence that listening can be taught, than it is to propose some constructive steps to increase our knowledge." A study by Petrie (11) investigated two methods of 1istening instruction and found no significant differences in either the direct or organization-oriented approach as opposed to the traditional technique. 
Research tends to support the premise that listening can be taught as any other skill. Charles Irvin (53) successfully employed seven listening training units in an experiment with 600 college students. Heilman (42) developed a series of six training lessons for the improvement of listening comprehension. Canfields' (33) experiment using 149 subjects taught by direct and indirect methods showed significant gains as measured on the STEP listening test. A study by Griffin and Hannah (59) in a short 1istening instructional program of four days found significant increases in 11stening ability as measured on the STEP 1istenIng test. Erickson (34) gave 309 subjects a twelve week course in systematic listening instruction and found significant increases as measured by the Brown-Carlsen. Using a pre-test, post-test design, Edinger. (60) used 241 subjects in a study where 163 received 1istening instruction by means of television, while the remainder received traditional instruction. He found significant gains in the televisiontaught group. Devine (61) employed ten twenty-two minute listening lessons in a study involving 445 junior high pupils and found that over a four week period their listening ability increased significantly. Brown (62), in a study of 48 college students, exposed 24 to a program of direct listening instructions while the remainder received traditional instruction. He found that the group taught directly scored better on the Brown-Carlsen. Numerous additional studies, Russell and Russel1 (63), Karraker (64), Hirsh (65), and Canute (66), point to the success of teaching the skills of listening comprehension.

The majority of authorities support the teachability of listening, but the same elements which account for its differing definitions have likewise given rise to differing approaches to teaching 1istening. One 
of the foremost authorities in the fleld of listening is Dr. Ralph G. Nichols at the University of Minnesota. Hardly any discussion of listening comprehension can transpire without numerous references to points or precepts which he has established. The present writer's indebtedness to Dr. Nichols is evidenced by the bibliography which follows. Dr. Nichols (56) lists ten bad listening habits which are most frequently encountered:

1. Condemning a speaker's subject as uninteresting before analyzing its values in terms of one's own future welfare.

2. Criticizing the speaker's delivery instead of concentrating on his message.

3. Preparing an answer to a point, or a question about a point, before comprehending the point.

4. Listening only for facts.

5. Wasting the advantage of thought speed over speech speed.

6. Tolerating or creating distractions which needlessly impair one's listening efficiency.

7. Faking attention to the speaker.

8. Permitting personal prejudices or deep-seated convictions to impair one's listening comprehension.

9. Avoiding listening to difficult expository material.

10. Trying to take notes in outline form in every instructional speaking situation.

Nichols suggests four skills to replace these bad 11stening habits: (1) analyze each topic for values to the listener personally, (2) listen for central ideas, (3) seek frequent exposure to difficult expository material, and (4) exploit fully the rate differential between thought and speech. As far as teaching the skills, Dr. Nichols suggests three methods: (1) direct instruction, (2) coordination of listening and speech instruction, and (3) the listening laboratory. 
The laboratory is a system that makes use of material on an individual basis, but not in a programmed sequence. A number of studies employing Nichols' suggestions seem to attest to their value. Hollingsworth (67) employed Nichols' approach in a twelve week listening instructional program and found statistically significant improvement by each group. Howard (68) used Nichols' ten rules for good listening as the basts of a pictorially presented method of listening instruction and concluded. that the elements did indeed provide a viable teaching basis. Keller (69) reports that the University of Minnesota employs the Nichols' approach as the foundation of its communication program.

Dow and Irvin (57) assume three types of listening: (1) discriminative, (2) critical, and (3) appreciative. In their discussion of the listening program at Michigan State University they describe a fourpart instructional program: (1) discuss the importance of listening with the pupils, (2) exercises in taking notes for the purpose of getting the central theme and main points of lectures, (3) exercises in listening to persuasive discourse, and (4) listening to recorded liter ature and discussing it afterwards. In their program, exercises meet the objectives of three kinds of listening.

Bird (70) introduces another approach to listening instruction as he describes the "Stephens College method" and its five steps. He lists the progressive steps as: (1) explaining the importance of listening, (2) an examination of the hearing-1istening process, (3) a discussion of factors which help or hinder the listening process, (4) a discussion of various ways in which listening can be improved, and (5) actual out-of-class practice of the acquired skills. Adams (71) tends to advocate a total skills approach to listening 
instruction. He contends that all listening training should have three distinct parts: (1) preparation for the act of listening, (2) actual participation in the listening situation, and (3) post-listening. In the employment of this approach the author emphasizes awareness, attention, and retention, and the activities which tend to promote these capacities will likewise be applicable to listening instruction. Ballenger (72) suggests that such a skills approach be employed in a sixteen week course of daily instruction with weekly testing.

In a somewhat different view of listening instruction, Canfield (73) posits certain requisites before any type of listening instruction can be used effectively. After fulfilling these requirements, however, one approach may be as effective as the other. Canfield suggests: (1) there should be adequate physical conditions, (2) experiences should be adjusted to the interest level, (3) there must be understanding and acceptance of the experience by the listener, (4) opportunities for self-expression must be present, (5) distractions must be minimized, (6) there should be good rapport established, and (7) there should be a variety of types of listening experiences.

Another philosophy concerning the teaching of listening skills is that of the integrative approach. The proponents of this technique would have listening taught in conjunction with another of the language arts. Brown and Keller (74) suggest that listening might be given a greater emphasis in the speech class and go on to present a proposal for such a program. Beery (75) argues that listening and reading are so closely related that they should be taught together in order to take advantage of this fact rather than thwart the two. Dow (76) agrees with the listening-reading combination. Baker (77) feels that 1istening can 
best be taught by the English teacher in conjunction with composition and consequently builds a case for such an approach. Francis (78) suggests and presents a plan to teach 1istening in conjunction with a four-year plan for the total language arts program in the high school. Elliff (79) capitalized on Nichols' suggested techniques for teaching 1istening and evolved an instructional program which emphasizes direct instruction, coordination of speech and 1istening instruction, and the use of a language ląboratory.

Perhaps one of the latest techniques to be considered in teaching listening comprehension skills is the use of the tape recorder and the concept of programmed instruction. It should be clear that this approach is more than "merely using the tape recorder" as employed in the Gallant study (80) of listening skills. The use of a programmed approach, like a good "human teacher," should, as Baker (81) points out, (1) present information in small steps (frames), (2) elicit responses, overtly or covertly, to questions and problems based on this information, (3) reveal correct and incorrect responses, and (4) encourage exposure to new information after learning the original material. There are two major programmed listening courses available on the market. The first of these is Listening: A Programmed Approach, published by McGraw-Hill. Along with the text, which uses numerous activities for each listening precept, there is a set of tape recordings. The second major program is Effective Listening, published by the Xerox Corporation. It contains two tapes, a response booklet, and has been widely used in both business and schools. Thomas King (82) comments, "A number of institutions have already included this program. If 1 istening can be taught, the use of this type of programming technique 
should be the most fruitful way to teach it."

Utilizing the theory of programmed instruction, some researchers have endeavored to apply its principles to the teaching of listening. E11a Erway (83), as an outgrowth of her Columbia University doctoral dissertation, published a taped programmed course in 1istening. A study by Barker and Wiseman (6) using 150 college students compared the effects of programmed and lecture presentations on listening achievement. Using a pre-test and post-test, they found no significant differences either on immediate or three-week delayed recall. A study by Binder and McGlone (7) using the Xerox Effective Listening Program, attempted to investigate the effects of programmed instruction on the teaching of listening to 20 subjects, but since the subjects were randomly assigned to three different treatments the size of the sample made their results of no significant difference dubious, at best.

It would appear that a study which could eliminate pre-test and post-test disadvantages, employ the requisite number of subjects per cell, and involve the use of a widely known and employed listening program could be beneficial. Such is the intent of this investigation.

\section{Summary}

The volume of research in the area of listening comprehension is indicative of the growing awareness of the need to nurture and develop instruction in this area. Studies relating to listening comprehension have occupied a large portion of the total research effort in speech communication education since 1950. Educators recognize the necessity of people having an understanding of listening skills and the Importance of its contribution to our livelihood. 
This chapter has attempted to review the 11terature relevant to the field of listening comprehension by first examining the area of listening definitions. While there are numerous definitions of the process, as well as the idea of "process"itself, most agree that listening involves the ability to associate meaning with audible symbols. Almost all authorities are in agreement that listening is of great importance. All seem to agree that any skill which demands one-half of our communicative time is worthy of consideration. Research indicates that listening gives way to reading as the preferred act of learning at approximately grade $6.6(30)$. A major theory as to the development of listening is espoused by Fessenden (46). A final area of analysis is that of teaching listening comprehension. Four basic approaches are investigated: (1) direct, (2) integrative, (3) eclectic, and (4) programmed. The programmed approach, being the most recent of the four, is the one utilized in the present study.

There is no known investigation completed or in progress which analyzes the comparative effectiveness of teaching listening comprehension by a "conventional" and "programmed" method when time of day is viewed as an experimental variable and the classes are taught by six different randomly assigned instructors. The present study endeavors to make such an analysis. 
CHAPTER III

DESIGN AND METHODOLOGY

Introduction

Speech 113 is a three semester-hour course which is required of all undergraduate students at Northeastern State College. According to the college catalog (84) the course is designed to provide the student with a basic understanding and appreciation of speech communication skills. Areas of emphasis include formal and informal speaking, discussion, parliamentary procedure, and listening. While the course is intended to be taken during the freshman year, there is nothing which prevents the student from taking it anytime prior to his graduation. The twenty-one sections. of the course, enrolling approximately 25-30 students per section, are presently taught by nịe full-time instructors。

The text which is presently used in the course is The Effective Speaker, second edition, by Huckleberry and Strother. While the chapters are not necessarily covered in numerical order, they are covered in the course of the semester. These chapters are:

Chapter 1. Effective Speaking: An Overview

Chapter 2. The First Classroom Speech

Chapter 3. Speech Purposes.

Chapter 4. Subjects and Sources

Chapter 5. Ideas and Development 


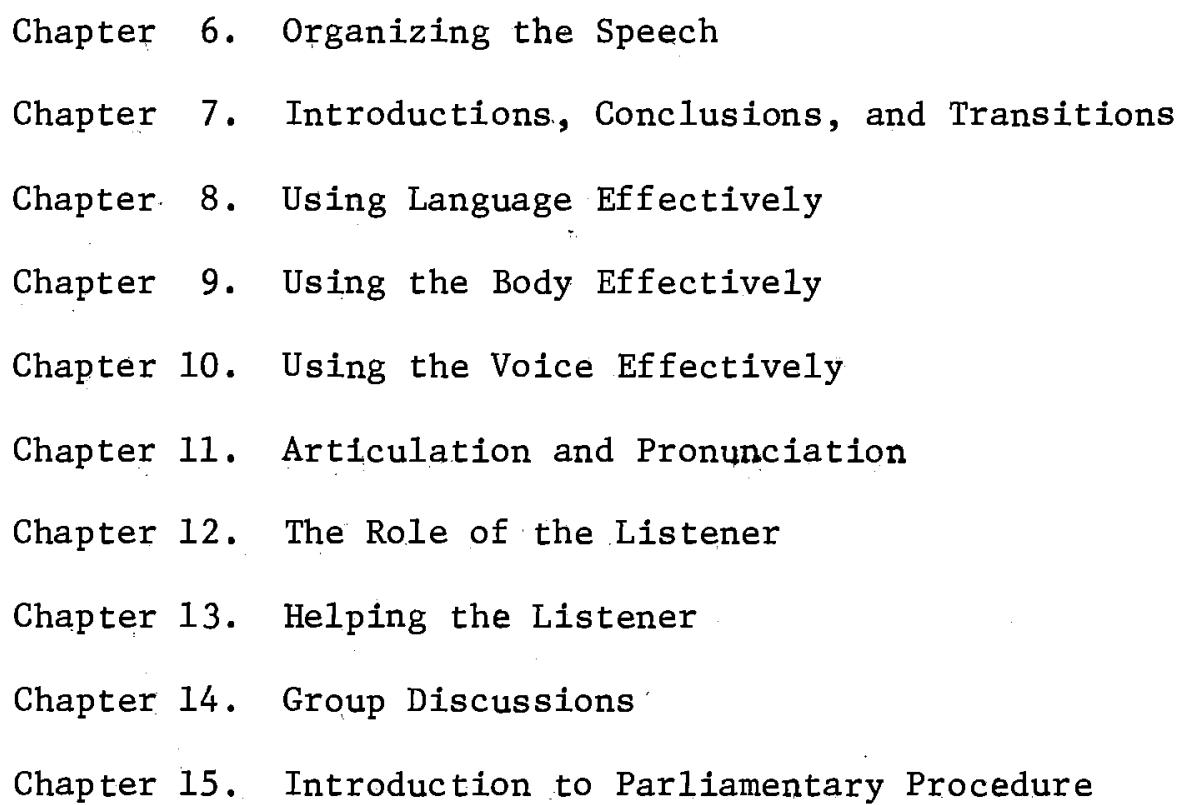

The emphasis of this study is upon the function of the listener in the oral communicative process. The specific purpose of the present investigation is to ascertain if listening comprehension can be more effectively taught by a programmed approach or a conventional approach.

\section{Research Design and Procedure}

There are numerous research designs which would be sufficient to meet the purpose of this study; however, one which could avoid the disadvantages of pre-testing and capitalize on the advantages of random assignment was preferred. Since random assignment of the subjects was possible, a two-factor completely randomized design was employed.

The desirability and usability of the two-factor completely randomized design is enunciated by numerous authorities. Bruning and Kintz (85) refer to this design as an extension of the completely randomized design which permits investigation of one set of variables in combination with another set. Thus, it is possible to determine whether or not the variables under consideration interact. 
Kerlinger (86) views it as the structure of research where two or more independent variables are juxtaposed in order to study their independent and interactive effects on a dependent variable. The experimental procedure for this design necessitates random assignment to the groups and manipulation of the two variables, followed by appropriate statistical analysis. Bruning and Kintz (85) posit three major points which should be considered when using the two-factor completely randomized design:

1. For each subject in the experimental groups, there can be only one score. As in the simple randomized design, if many measures are taken for each subject, these must be combined so that there is only one score for each subject.

2. It is usually best to have an equal number of subjects in each of the experimental groups. If equality cannot be obtained, the number of subjects in each group should be proportional.

3. The number of treatment groups within each factor that may be compared is arbitrary. However, it is rare that more than four or five groups are included in either of the two factors.

In the present investigation six sections of the basic Speech 113 classes were selected to be included. Two sections were selected from the 8:00 A.M. period, two from the 10:00 A.M. period, and two from the 1:00 P.M. period. One section at each time period was randomly designated the experimental class and received the programmed approach to listening improvement, while each remaining section was designated the control class and received the conventional method of instruction. Subjects were randomly assigned to the six sections and six different instructors were randomly assigned to teach the classes in the study. Both the experimental and control groups received training for the same period of time. At the conclusion of the study both groups took form 
BM of the Brown-Carlsen Listening Comprehension Test and completed an attitude questionnaire concerning the method of instruction they received.

This design was employed to test the following cluster hypotheses:

I. There is no significant difference in the listening achievement scores of freshmen enrolled in Speech 113 at Northeastern State College due to the use of programmed 1istening instruction as opposed to the conventional method of instruction.

II. There is no significant difference in the listening achievement scores of freshmen enrolled in Speech 113 at Northeastern State College due to the time of day listening instruction is received.

III. There is no significant difference in the listening achievement scores of freshmen enrolled in Speech 113 at Northeastern State College due to the interaction of method of listening instruction and time of day instruction is recelved. IV. There is no significant difference in the listening achievement scores of freshmen enrolled in Speech 113 at Northeastern State College due to the method of listening instruction received, time of day the instruction is received, or the interaction of method and time of day relative to:

A. Listening for immediate recall.

B. Listening to follow directions.

C. Listening to recognize transitions.

D. Listening to recognize word meanings.

E. Listening for lecture comprehension. 
Population and Sample

Those students who enroll in Speech 113 at Northeastern State Co1lege represent all of the undergraduate classifications. This study, however, was concerned with only freshman students. Other students who were in the six classes were given equal treatment, but their performances were not considered in the data analysis.

The subjects for this investigation were selected on a "first come, first serve" basis from the spring 1972 freshman class at Northeastern State College. Because it was not possible to secure random selection from the total freshman class, the population for this investigation is limited to the members of the study. The subjects in this study were randomly assigned to one of the six classes by the freshman counseling office at Northeastern. The counselors maintained a running tally of the number in each class as well as a record of all members who were not freshmen and consequently were excluded from analysis.

The Programmed Materials

The programmed material used in this investigation was the Xerox Effective Listening Program which is a unit of the Communication Skills Programs published by the Xerox Corporation. The program consists of an administration manual, two examination tapes, two program tapes, and a response book. The two examination tapes contaln listening situations which permit appraisal of students' 1istening comprehension ability before and after they have taken the program. The program tapes consist of 54 frames which constitute the listening episodes of the Effective Listening Program and can be administered in a minimum of 
three hours. The response book is the instrument in which the subject records his response to each frame of the program. The book is "consumable" in that the correctness of each response is ascertained by detaching a perforated page which reveals the correct answer. Thus the student is provided immediate feedback regarding the adequacy of his response.

The Xerox program (87) addresses itself to the improvement of listening in general by directly emphasizing the following aspects of listening comprehension: recognizing the importance of listening, mentally editing what is heard, organizing main and subordinate points, overcoming distractions, summarizing and paraphrasing, and the use of key words. The frames of the program depict listening situations which necessitate the use of one or more of these techniques.

"Recognizing the importance of listening" is accomplished by the inclusion of a brief article by Ralph G. Nichols which emphasizes the need for effective listening in all aspects of oral communication. In addition to this the speaker on the tape orally emphasizes Nichols' written remarks and continually reinforces the importance of listening throughout the program.

"Mentally editing what is heard" is necessitated since many of the program frames include information which is unnecessary or superfluous to the meaning of the statement. Consequently, the listener is forced to "cut away" the non-restrictive material in order to effectively retain that information which is vital to correctly understanding what is heard.

"Organizing main and subordinate points" is developed by stressing the basic elements of outlining. The program urges the student to 
order and structure the information he hears into outline form so as to be better enabled to see relationships as well as improve retention. This aspect is employed in almost every frame and the relation between order, understanding, and retention totally justify its emphasis.

"Overcoming distractions" is uniquely treated by the program. Each frame presents the voice of a different speaker and as such provides a multiplicity of accents, emotions, and oral styles. This necessitates that the listener be flexible and adjust to each speaker as an individual in order to do the best job of listening. In addition, many frames depict "outside noises" such as telephones ringing, other conversation in progress, and the clacking of typewriters which must be overcome in order to concentrate on the central oral stimulus--that to which one is supposedly listening.

"Summarizing and paraphrasing" serves as an important aspect of listening. Many of the frames present information which is so brief or presented in such a manner that it cannot be effectively outlined. Thus, with this type of information the listener is taught to employ a mental summary or paraphrase of what is heard. Emphasis is placed on correctly abbreviating the message, however.

"The use of key words" compliments all of the previous areas of emphasis in the Xerox program. By remembering the key words in certain sentences or paragraphs one is better equipped to outline, summarize, paraphrase, overcome distractions, and edit the oral message. The program provides many opportunities for the listener to retain the "gist" of a message by isolating certain key words or concepts. 
The Measuring Instruments

Two instruments were used in the study. The first, the BrownCarlsen Listening Comprehension Test (17), Form BM, was used to determine the subjects' listening comprehension achievement after receiving instruction in either the control or experimental group. The second instrument was an attitude questionnaire concerning the method in which instruction had been received.

The Brown-Carlsen (17), which contains 76 items, measures what experimental tryouts indicate are five basic aspects of listening:

1. Immediate Recall - Measures the ability to keep a sequence of details in mind until a question is asked which requires thinking back over the sequence.

2. Following Directions - Measures the ability to follow oral directions.

3. Recognizing Transitions - Measures awareness of the function of transitional words and phrases within sentence context.

4. Recognizing Word Meanings - Measures the ability to recognize meanings of words from context.

5. Lecture Comprehension - Measures the ability to

1isten for details, get the central idea, draw inferences, understand the organization, and note degree of relevancy in a brief lecture presentation.

Concerning the validity of the test, the examiner's manual states

that the authors sought to insure content validity by virtue of:

- - (1) pronouncements of the Commission on the English Curriculum of the National Council of Teachers of English, (2) conclusions reached by Nichols in his survey of factors in listening comprehension, (3) study of diagnostic tests in silent reading, and (4) the opinion of eleven experts, chosen largely from among the members of the Vertical Committee on Listening of the NCTE.

Additionally, the authors of the test constructed two experimental forms of the test. Both forms were critiqued by a panel of authorities 
regarding difficulty, interest, clarfty of directions, time limits, and suitability of content. These analyses and criticisms were considered in the evolution of the final form of the test. An investigation of the construct validity of the Brown-Carlsen and the Sequential Tests of Educationa1 Preparation Listening Test undertaken by Ke11y (88) led him to conclude that the Brown-Carlsen is not only superior to the STEP, but that form BM had the highest construct validity of the four instruments of the two tests. It should be noted, however, that in view of his methodology, Professor Kelly appears possibly to have investigated the concurrent validity of the tests rather than the construct validity. According to Buros' Fifth Mental Measurements Yearbook' (89) the Brown-Carlsen has a split-half reliability of .86 while the instruction manual (17) states that the standard error of measurement is 5.0 standard score points. Since the test was designed and normed for students of this grade level, was constructed and standardized by a respectable publisher, and measures skills relevant to this investigation, it was considered applicable to the subjects of this study.

The second instrument used in this investigation was a questionnaire which focused upon the subjects' attitudes or feelings toward the method of listening instruction they received. The questionnaire is a Likert type, summated scale, which asked the subjects to express their feelings toward the instruction by responding to such questions as, "If fee'l that I better appreciate the importance of listening skills as a result of the instruction." Alternative responses ranged from Ustrongly disagree, disagree, neutral, agree, to strongly agree," and were supplied weighted values from one to five (Appendix). The questionnaire itself is a modified form of the one which is included in the 
Xerox program (87) and one used by Binder and McGlone (7) in their analysis of the program. Attesting to the appropriateness of the summated scale for an investigation such as the present one, Kerlinger (86) notes, "Of the three types of scales, the summated rating scale seems to be the most useful in behavioral research." The constructors attempted to insure content validity of the instrument by constructing it in view of having examined the Xerox questionnaire, research studies : related to the teaching of listening comprehension, and books as a basis for determining the knowledge and understanding to be considered. A split-half reliability of .71 was found using the Spearman-Brown prophecy formula for correction.

Complete anonymity was maintained in an attempt to secure the unbiased opinion of the subjects. The tabulated results of the questionnaire will appear in Chapter IV which is concerned with the analysis of the data.

The Statistical Treatment

The statistical technique used to determine the significance of the results in this study was the analysis of variance. The acceptance level was set at the .05 level of significance. As a prerequisite to the analysis of variance, a statistical check on the heterogeneity was also conducted.

In their description of the analysis of variance technique, Runyon and Haber (90) state:

The analysis of variance is a technique of statistical analysis which permits us to overcome the ambiguity involved in assessing significant differences when more than one comparison is made. It allows us to answer the question: Is there an overall indication that the experimental treatments 
are producing differences among the means of the various groups? Although the analysis of variance may be used in the two-sample case (in which event it yields precisely the same probability values as the Student t-ratio), it is most commonly employed when three or more groups are involved. Indeed, it has its greatest usefulness when two or more independent variables are studied.

Hence, the analysis of variance technique was used on the composite achievement scores on the Brown-Carlsen Listening Comprehension Test as well as on each of its five sub-scales. The results of the attitude questionnaire are expressed in tabular form.

Summary

This chapter has been concerned with the procedures, research design, population and sample, programmed materials, measuring instruments and statistical treatment which are employed in this investigation. Additionally, it has briefly considered the Speech 113 program at Northeastern State College where the investigation was undertaken. The data for this study were collected during the spring, 1972, semester during the first four weeks of regularly scheduled classes. The study was initiated to ascertain if there were any significant differences in listening achievement by students who were assigned to the control group, and received conventional listening instruction, and those assigned to the experimental group, who received the Xerox programmed approach to listening improvement. A second variable, time of instruction, was also investigated.

The next chapter will present the statistical analysis of the results of the subjects' scores on the Brown-Carlsen Listening Comprehension Test using the analysis of variance technique. A presentation of the results of the attitude questionnaire will also be included. 
CHAPTER IV

REPORTING THE STUDY

The analysis of data regarding the listening comprehension of students in Speech 113 at Northeastern State College is presented in this chapter. The major purpose of this study was to compare the effectiveness of two methods of teaching listening comprehension skills to college freshmen when time of instruction was also viewed as a variable. Comparisons of effectiveness were made in the areas of listening for immediate recal1, 1istening to follow directions, listening to recognize the transitions, listening to recognize word meanings, and listening for lecture comprehension.

A secondary purpose of this investigation was to examine the attitudes of the subjects toward the method of instruction they received. This information was secured through a Likert-type attitude questionnaire.

Specific hypotheses tested in this investigation are as follows:

I. There is no significant difference in the listening achievement scores of freshmen enrolled in Speech 113 at Northeastern State College due, to the use of programmed listening instruction as opposed to the conventional method of instruction.

II. There is no significant difference in the listening achievement scores of freshmen entolled in Speech 113 at Northeastern State College due to the time of day listening instruction is 
received.

III. There is no significant difference in the listening achievement scores of freshmen enrolled in Speech 113 at Northeastern State College due to the interaction of method of listening instruction and time of day instruction is received.

IV. There is no significant difference in the listening achievement scores of freshmen enrolled in Speech 113 at Northeastern State College due to the method of listening instruction received, time of day the instruction is received, or the interaction of method and time of day relative to:

A. Listening for immediate recall.

B. Listening to follow directions.

C. Listening to recognize transitions.

D. Listening to recognize word meanings.

E. Listening for lecture comprehension.

The six classes involved in this study contained a total enrollment of 128 students. However, since the present investigation was concerned with the listening ability of freshmen students only, the scores of non-freshmen were excluded from the study. This exclusion resulted in a total of 93 freshmen subjects. In order to secure an equal number of subjects per class and thus facilitate subsequent statistical treatment; one freshman was randomly dropped from the 8:00 experimental section and two freshmen subjects were randomly dropped from the 8:00 control class. This procedure resulted in an equal number of 15 subjects per class and a total of 90 subjects in the study. The results of this action are depicted in Table $I$. 
TABLE I

DISTRIBUTION OF SUBJECTS BY CLASSES

\begin{tabular}{ccccc}
\hline Class & $\begin{array}{c}\text { Class } \\
\text { Enrollment }\end{array}$ & $\begin{array}{c}\text { Freshman } \\
\text { Enrollment }\end{array}$ & $\begin{array}{c}\text { Freshmen } \\
\text { Dropped }\end{array}$ & $\begin{array}{c}\text { Total. } \\
\text { Subjects }\end{array}$ \\
\hline $8: 00$ (E) & 22 & 16 & 1 & 15 \\
$8: 00$ (C) & 27 & 17 & 2 & 15 \\
$10: 00$ (E) & 25 & 15 & 0 & 15 \\
$10: 00$ (C) & 19 & 15 & 0 & 15 \\
$1: 00$ (E) $:$ & 17 & 15 & 15 & 15 \\
$1: 00$ (C) & 18 & 15 & 0 & 90 \\
TOTAL & 128 & 93 & 3 & 15 \\
\hline
\end{tabular}

(E) indicates the experimental group

(C) indicates the control group

Description of Data and Testing of Hypotheses

The two-factor analysis of variance statistic was used to analyze the data relevant to the hypotheses in this investigation. This statistic allows a comparison of the performance of those subjects who received listening comprehension instruction by the experimental or programmed approach at the hours of 8:00, 10:00, and 1:00 with those subjects. who received the conventional or controlled method of instruction at the same hours.

The two-factor analysis of variance assumes homogeneity of variances. Since the subjects in this study were assigned on a random 
basis, it was assumed that the groups possessed homogeneous variances. To evaluate this assumption, a variance check was made using Hartley's F Maximum Test for Homogeneity of Variances on the variances resulting from the statistical analysis of the Brown-Carlsen composite score and sub-scale scores.

The results of the analysis of variance are summarized and reported in Tables II through VII. A11 results were evaluated at the .05 leve1 of significance.

The hypotheses tested and action taken on them are as follows:

I. There is no significant difference in the 1istening achievement scores of freshmen enrolled in Speech 113 at Northeastern State College due to the use of programmed listening instruction as opposed to the conventional method of instruction.

Preliminary analysis of the student's composite scores indicated that 40 per cent (17) of the subjects in the experimental group scored in the upper quartile of the Brown-Carlsen while the remaining 60 per cent (28) scored in the upper middle quartile. Synonymous evaluation of the control group revealed that 18 per cent (8) scored in the upper quartile, 76 per cent (34) scored in the upper middle quartile, and 6 per cent (3) scored in the lower middle quartile. Thus, the experimental group surpassed the control group quantitatively.

Using Hatley's test for homogeneity of variances, an $F$ max ratio of 8.61 was derived. Since 8.61 is greater than the table value of 4.68 (14 df and $\mathrm{K}=6$ ) required for significance at the .05 level, the variances were deemed to be heterogeneous.

The mean of the experimental group was found to be 53.91, while the mean of the control group was established as 49.84 . Thus, the 
experimental group's performance exceeded that of the group which was taught by conventional methods. The computed $F$ value of 7.75 is greater than the table value of 4.00 required for significance at the .05 leve1 ( 1 and $84 \mathrm{df}$ ); additiona11y, the obtained $\mathrm{F}$ value of 7.75 was found significant at the .01 level which indicates that there is one chance in one hundred that this outcome was a "chance happening." Therefore, the null hypothesis was rejected and the alternate hypothesis that "there is a significant difference in the listening achievement scores of freshmen enrolled in Speech 113 at Northeastern State College due to the use of programmed listening instruction as opposed to the conventional method of instruction" was accepted. (Table II)

II. There is no significant difference in the listening achievement scores of freshmen enrolled in Speech 113 at Northeastern State College due to the time of day listening instruction is received.

In order to investigate the variable of "time of day instruction is received," three time periods were randomly selected from the hours that Speech 113 was being offered. The periods chosen were 8:00, 10:00, and 1:00. Two classes were then selected from each of the periods and one was taught by the programmed method while the other received instruction by a conventional approach.

The mean of each group with regard to the variable of "time": was 51.73 at $8: 00 ; 49.70$ at $10: 00$; and 54.20 at $1: 00$. The computed $F$ value of 3.17 is greater than the table value of 3.15 required for significance at the .05 level ( 2 and $89 \mathrm{df}$ ). Consequently, the null hypothesis was rejected and the alternate hypothesis that "there is a significant difference in the 1 istening achievement scores of freshmen 
enrolled in Speech 113 at Northeastern State College due to the time of day 1istening instruction is received" was accepted. (Table II)

In an attempt to determine which of the hours differed to provide the significant F value, Duncan's Multiple Range Test for Effects was employed as a follow-up test. The results of the follow-up test indicated that when the 8:00 hour was compared with the 10:00 hour, the derived value was 2.03 which is below 3.579 required for significance (84 $\mathrm{df}$ and $\mathrm{K}=2$ ). When the 8:00 hour was compared with the 1:00 hour, the derived value was 2.47 which is below 3.579 required for significance ( $84 \mathrm{df}$ and $\mathrm{K}=2$ ). When the 10:00 hour was compared with the 1:00 hour, however, the derived value was 4.50 which is greater than 3.765 required for significance ( $84 \mathrm{df}$ and $\mathrm{K}=3$ ). Thus, while the comparative performance of the 8:00 hour with the 10:00 hour and the 8:00 with the 1:00 did not differ significantly, the 10:00 hour and the 1:00 hour did display a significant difference with 1:00 being the preferred time period. Consequently, the teaching of 1istening comprehension on a composite basis appears more successful at 1:00 than 10:00, with 8:00 not being significantly different from either 10:00 or 1:00.

III. There is no significant difference in the listening achievement scores of freshmen enrolled in Speech 113 at Northeastern State College due to interaction of method of listening instruction and time of day instruction is received.

The purpose of testing this hypothesis was to see if a particular method of instruction combined with a particular hour to produce a significant difference in listening ability. The computed $F$ value of 0.27 was less than the table value of 3.15 required for significance at the .05 leve1 ( 2 and $84 \mathrm{df}$ ). Thus, the nu11 hypothesis was indeed accepted. 
TABLE II

ANALYSIS OF VARTANCE OF METHOD OF TEACHING

LISTENING COMPREHENSION AND TIME OF

DAY INSTRUCTION WAS RECEIVED

(COMPOSITE SCORE)

\begin{tabular}{lccccc}
\hline \multicolumn{1}{c}{ Source } & S.S. & df & M.S. & F & P \\
\hline Tota1 & 4735.81 & 89 & 53.21 & -- & \\
$\begin{array}{l}\text { Method of } \\
\text { Instruction }\end{array}$ & 372.25 & 1 & 372.25 & 7.75 & .01 \\
$\begin{array}{l}\text { Time of Day } \\
\text { Method X Time }\end{array}$ & 304.81 & 2 & 152.41 & 3.17 & .05 \\
& 26.31 & 2 & 13.16 & 0.27 & N.S. \\
Error & 4032.44 & 84 & 48.01 & -1 & -- \\
\end{tabular}


Table II depicts these results.

The following hypotheses constitute a "cluster." Each hypothesis, while being tested on the same variables of "method of instruction" and "time of day instruction is received," is actually a sub-scale of the Brown-Carlsen Listening Comprehension Test.

IV-a. There is no significant difference in the listening achievement scores of freshmen enrolled in Speech 113 at Northeastern State College due to method of instruction, time of day instruction is received, or the interaction of method and time relative to "listening for immediate recal1."

The sub-scale of "1istening for immediate recall" contains a total of 17 items which require the student to immediately recall that to which he has just listened. The amount of time between test items is approximately five seconds.

Using Hartley's test for homogeneity of variances, an $F$ max ratio of 5.49 was derived. Since 5.49 is greater than the table value of 4.68 required for significance at the .05 level (14 $\mathrm{df}$ and $\mathrm{K}=6$ ), the variances were determined to be heterogeneous.

The table value necessary for significance with regard to "method of instruction" is 4.00. The computed $F$ value was found to be 2.08; therefore, the null hypothesis was accepted. (Table III)

The group means for "time of day instruction was received" were found to be 12.23 at $8: 00 ; 11.60$ at $10: 00$; and 13.26 at $1: 00$. The table value necessary for significance with reference to the variable of "time" is 3.15. The computed value was found to be 4.14; therefore, the null hypothesis was rejected and the alternate hypothesis that "there is a significant difference in the '1istening for immediate 
recal1' scores of freshmen enrolled in Speech 113 at Northeastern State College due to the time of day the instruction is received" was.

accepted. (Table III)

In order to ascertain the order of differences which occurred to produce the significant effect, Duncan's Multiple Range Test for Effects was employed. When the 8:00 hour was compared with the 10:00 hour, the derived value was 0.63 which is less than 1.167 required for significance ( $84 \mathrm{df}$ and $\mathrm{K}=2$ ). When the 8:00 hour was compared with the 1:00 hour, the obtained value was 1.03 which is less than 1.167 required for significance ( $84 \mathrm{df}$ and $\mathrm{K}=2$ ). When the 10:00 hour was compared with the 1:00 hour, the obtained value was 1.66 and exceeded 1.227 required for significance ( $84 \mathrm{df}$ and $\mathrm{K}=3$ ). Thus, while the comparative performance of the 8:00 hour with the 10:00 hour and the 8:00 period with the 1:00 period were not significantly different, the 10:00 and 1:00 hours did differ significantly. Therefore, the teaching of "1istening for immediate recal1" appears more successful at 1:00 than 10:00 with 8:00 not being significantly different from either 10:00 or $1: 00$.

The tabled $F$ value necessary for significance with regard to "interaction of method of instruction and time of day instruction is received," is 3.15. The computed F value for interaction was 0.70 . Therefore, the null hypothesis was accepted. (Table III)

IV-b. There is no significant difference in the listening achievement scores of freshmen enrolled in Speech 113 at Northeastern State College due to the method of listening instruction received, time of day instruction is received, or the interaction of method and time relative to 
TABLE III

ANALYSIS OF VARIANCE OF METHOD OF TEACHING

LISTENING COMPREHENSION AND TIME OF

DAY INSTRUCTION WAS RECEIVED

(IMMEDIATE RECALL)

\begin{tabular}{lccccc}
\hline Source & S.S & df & M.S. & F & P \\
\hline Total & 490.90 & 89 & 5.52 & - & \\
$\begin{array}{l}\text { Method of } \\
\text { Instruction }\end{array}$ & 10.68 & 1 & 10.68 & 2.08 & N.S. \\
$\begin{array}{l}\text { Time of Day } \\
\text { Method X Time }\end{array}$ & 72.47 & 2 & 21.23 & 4.14 & .05 \\
& & & & & \\
Error & 430.54 & 84 & 3.61 & 0.70 & N.S. \\
\hline
\end{tabular}


"1istening: to follow directions."

"Yistening to follow directions" necessitates that the student be able to follow oral directions in order to select the appropriate alternatives in a particular situation in question. The sub-scale contains 20 items.

Hartley's test for homogeneity of variances yielded an $F$ max ratio of 7.38 which exceeds the table value of 4.68 required for significance at the .05 level ( $14 \mathrm{df}$ and $\mathrm{K}=6$ ): Thus, the variances were determined to be heterogeneous.

The mean of the experimental group was found to be 16.55 while the mean of the control group was established as being 13.53. The tabled F value requisite for significance with regard to "method of instruction" is 4.00. The obtained F value, however, was 21.54. Therefore, the null hypothesis was rejected and the alternative hypothesis that "there is a significant difference in the '1istening to follow directions' scores of freshmen enrolled in Speech 113 at Northeastern State College due to method of instruction received" was accepted. Additionally, the obtained $F$ value of 21.54 is significant at the .001 level. Thus, the chances that this result occurred by "chance" are less than one in onethousand. (Table IV)

While an $F$ value of 3.15 is required for significance of "time of day instruction was received," the computed $F$ value was 2.66 . Therefore, the null hypothesis was accepted. (Table IV)

In analyzing the "interaction between method and time of instruction" an F value of 3.15 is necessary for significance. Since the derived value was 1.48 , the null hypothesis was accepted. (Table IV) IV-c. There is no significant difference in the listening 
TABLE IV

ANALYSIS OF VARIANCE OF METHOD OT TEACHING

LISTENING COMPREHENSION AND TIME OF

DAY INSTRUCTION WAS RECEIVED

(FOLLOWING DIRECTIONS)

\begin{tabular}{|c|c|c|c|c|c|}
\hline Source & $S . S$ & $\mathrm{df}$ & M.S: & $F$ & $\mathrm{P}$ \\
\hline Total & 1085.82 & 89 & 12.20 & -- & - \\
\hline $\begin{array}{l}\text { Method of } \\
\text { Instruction }\end{array}$ & 205.51 & 1 & 205.51 & 21.54 & .001 \\
\hline Time of Day & 50.69 & 2 & 25.34 & 2.66 & N.S. \\
\hline Method X Time & 28.16 & 2 & 14.08 & 1.48 & N.S. \\
\hline Error & 801.47 & 84 & 9.54 & -- & $-\infty$ \\
\hline
\end{tabular}


achievement scores of freshmen enrolled in Speech 113 at Northeastern State College due to method of listening instruction received, time of day instruction is received, or the interaction of method and time relative to "listening to recognize transitions."

The sub-scale of "recognizing transitions" requires the student to identify transitional wording which may indicate the approach of a summary of what has been said, a new point about to be introduced, or a concluding statement. There are eight items in this scale and the students are allowed approximately five seconds to record their responses to each.

Hartley's test for homogeneity of variances produced an $\mathrm{F}$ max ratio of 7.56 which exceeds the table value of 4.68 required for significance at the .05 leve1 ( $14 \mathrm{df}$ and $\mathrm{K}=6$ ). Thus, the variances were deemed to be heterogeneous.

With regard to "method of instruction," the derived $F$ value of 1.50 was established; however, a table value of 4.00 is required for significance. Therefore, the null hypothesis of no significant difference was accepted. Neither method was shown to be significantly more effective than the other for teaching the recognition of transitions. (Table V)

The variable of "time" necessitates a computed F value greater than 3.15 for significance. Since the computed value was 0.93 , the nu11 hypothesis was accepted. (Table V)

An $F$ value of 3.15 is required for significance of "interaction between method and time of instruction." The derived value was 1.07; consequent1y, the null hypothesis was accepted. (Table V) 
TABLE V

ANALYSIS OF VARIANCE OF METHOD OF TEACHING

LISTENING COMPREHENSION AND TIME OF

DAY INSTRUCTION WAS RECEIVED

(RECOGNIZING TRANSITIONS)

\begin{tabular}{lccccc}
\hline \multicolumn{1}{c}{ Source } & S.S & df & M.S. & F & P \\
\hline Tota1 & 129.56 & 89 & 1.46 & -- & \\
$\begin{array}{l}\text { Method of } \\
\text { Instruction }\end{array}$ & 2.18 & 1 & 2.18 & 1.50 & N.S. \\
$\begin{array}{l}\text { Time of Day } \\
\text { Method X Time }\end{array}$ & 3.09 & 2 & 1.34 & 0.93 & N.S. \\
& 2.69 & 1.54 & 1.07 & N.S. \\
Error & 121.60 & 84 & 1.45 & - & - \\
\hline
\end{tabular}


IV-d. There is no significant difference in the listening achievement scores of freshmen enrolled in Speech 113 at Northeastern State College due to method of listening instruction received, time of day instruction is received, or the interaction of method and time relative to "listening to recognize word meanings."

In "recognizing word meanings" the subjects are orally presented two sentences in which a previously designated word is used differently. Consequently, the meaning of each sentence differs depending upon the use of the word. This sub-scale contains ten items which concern themselves with the dual use of five different words.

Differing from the previous results, Hartley's test for homogeneity of variances indicated an $F \max$ ratio of 2.74 . Since the value was less than the table value of 4.68 required for significance at the .05 level ( $14 \mathrm{df}$ and $\mathrm{K}=6$ ), the variances were determined to be homogeneous. A table value of 4.00 is required for significance of "method of instruction," however the computed F value was 1.49 . Thus, the null hypothesis was accepted. (Table VI)

"Time of day instruction was received" necessitates an obtained F value in excess of 3.15 for significance. Since the attained $F$ value was 0.41 , the null hypothesis of wo significant difference was accepted with regard to "time." (Table VI)

Since "interaction of method of instruction and time of day instruction was received" had been insignificant on all previous hypotheses, it was not surprising that the same was true here. The obtained $F$ value was 0.25 which is well below the 3.15 required for significance; hence, the null hypothesis was accepted. (Table VI) 
TABLE VI

ANALYSIS OF VARIANCE OF METHOD OF TEACHING

LISTENING COMPREHENSION AND TIME OF

DAY INSTRUCTION WAS RECEIVED

(WORD MEANINGS)

\begin{tabular}{lccccc}
\hline Source & S.S. & df & M.S. & F & P \\
\hline Total & 187.39 & 89 & 2.11 & - & \\
$\begin{array}{l}\text { Method of } \\
\text { Instruction }\end{array}$ & 3.21 & 1 & 3.21 & 1.49 & N.S. \\
$\begin{array}{l}\text { Time of Day } \\
\text { Method X Time }\end{array}$ & 1.09 & 2 & 0.88 & 0.41 & N.S. \\
Error & 181.34 & 84 & 0.54 & 0.25 & N.S. \\
\hline
\end{tabular}


IV-e. There is no significant difference in the listening achievement scores of freshmen enrolled in Speech 113 at Northeastern. State College due to the method of 1istening instruction received, time of day the instruction is received, or the interaction of method and time relative to "listening for lecture comprehension."

"tistening for lecture comprehension" is the final sub-scale of the Brown-Carlsen. The subjects are read a 15 minute lecture and then asked to respond to a series of 21 questions dealing with the content of the lecture.

Because most of the teaching techniques in higher education are either totally or partially based on the lecture method of instruction, the writer awaited the results of the subjects' performance on this sub-scale with great anticipation. Quantitative results indicated that not only was there no difference between the experimental and control groups, but that they were distributed synonymous1y; 18 per cent (8) scored in the upper one-third, 71 per cent (32) scored in the middle one-third, and 11 per cent (5) scored in the lower one-third.

Hartley's test for homogeneity of variances yielded an $\mathrm{F}$ max ratio of 3.77 which was below the table value of 4.68 required for significance. Thus, the variances were deemed to be homogeneous.

The results of the statistical analysis of "method of instruction" showed that the $F$ value was 0.19 . Since that value is less than the 4.00 required for significance, the null hypothesis was accepted. (Table VII)

When "time of day instruction was received" was analyzed, it was found to possess a computed value of 0.21 which is below the table 
TABLE VII

ANALYSIS OF VARIANCE OF METHOD OF TEACHTNG

LISTENING COMPREHENSION AND TIME OF

DAY INSTRUCTION-WAS RECEIVED

(LECTURE COMPREHEÑSION)

\begin{tabular}{lccccc}
\hline Source & S.S. & df & M.S. & F & P \\
\hline Total & 824.90 & 89 & 9.27 & - & \\
$\begin{array}{l}\text { Method of } \\
\text { Instruction }\end{array}$ & 1.88 & 1 & 1.88 & 0.19 & N.S. \\
$\begin{array}{l}\text { Time of Day } \\
4.07\end{array}$ & 2 & 2.03 & 0.21 & N.S. \\
Method X Time & 6.82 & 2 & 3.41 & 0.35 & N.S. \\
Error & 812.14 & 84 & 9.67 & - & - \\
\hline
\end{tabular}


value of 3.15 necessary for significance. Thus, the null hypothesis of no significant difference was accepted. (Table VII)

An $F$ value of 3.15 is required for significance of "interaction between method and time of instruction." The obtained value, however, was found to be 0.35 . Consequently, the null hypothesis was accepted. (Table VII)

\author{
Analysis of Questionnaires Relative \\ to Method of Instruction
}

A fikert-type questionnaire regarding the students' attitudes toward the method of instruction they received was administered to the six classes at the completion of the study (Appendix). While anonymity was maintained, the students were instructed to indicate their college classification on the questionnaire. A total of 128 students responded to the questionnaire of which 93 indicated their classification as freshman. The remaining 35 , being upperclassmen, were excluded from the study. The questionnaire of one subject was dropped from the 8:00 experimental group, and two were randomly dropped from the 8:00 control group. It was on this basis that the same subjects' scores on the Brown-Carlsen test were also dropped, thereby securing an equal number of 15 subjects per class and a total of 90 subjects in the investigation.

The range of alternatives in the questionnaire included "Strongly Agree": (SA), "Agree" (A), "Neutral" (N), "Disagree". (D), and "Strongly Disagree" (SD). The responses were assigned values of $5,4,3,2$, and 1 respectively. Since there were 14 items included on the questionnaire, there was a total possible score of $70(14 \times 5)$. The average 
total response for the two methods of instruction is presented in Table VIII.

TABLE VIII

AVERAGE QUESTIONNAIRE RESPONSE TOWARD

INSTRUCTIONAL METHOD RECEIVED

\begin{tabular}{cc}
\hline $\begin{array}{c}\text { Method of } \\
\text { Instruction }\end{array}$ & $\begin{array}{c}\text { Mean } \\
\text { Score }\end{array}$ \\
\hline Programmed & 50.54 \\
Conventional & 48.74 \\
\hline
\end{tabular}

A more complete analysis of the students' attitudes can be made by examining the intensity of their feelings toward the major concepts which are inherent within the questionnaire. The intensity of attitudinal responses of the two groups toward the method of instruction received is depicted in Table IX. The questionnaire items relating to the students' attitude toward the "carry-over, value" of the instruction are grouped under a single heading (items $1,6,8,9,10,12$, and 13 of the Appendix). The remaining items are concerned with the students' attitude toward the "appropriateness of the instructional method" and are grouped under that subsequent heading, (items $2,3,4,5,7,11$, and 14 of the Appendix). As indicated by the information available in 
TABLE IX

FREQUENCY OF - RESPONSE OF

ATTITUDE INTENSITY

\section{Experimental}

Carry-over Value

Appropriateness

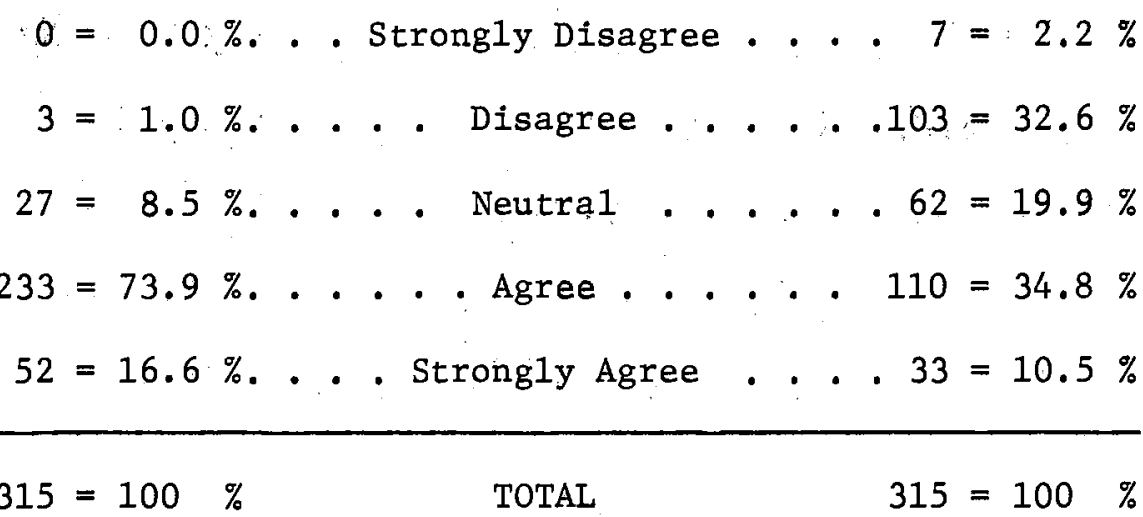

Conventiona1

$$
\begin{aligned}
& 1=0.3 \% \text {. . Strongly Disagree... } 21=6.6 \% \\
& 12=3.8 \% \text {. . . Disagree . . . . } 104=33.3 \% \\
& 36=11.4 \% \text {. . . Neutral .... } 66=20.9 \% \\
& 206=65.4 \% \text {..... Agree ..... } 92=29.1 \% \\
& 60=19.1 \% \text {. . . Strongly Agree . . . } 32=10.1 \% \\
& 315=100 \% \quad \text { TOTAL } \quad 315=100 \%
\end{aligned}
$$


Tables VIII and IX, the students display a slight preference for the programmed instructional method.

\section{Summary}

This chapter has presented the findings of the present investigation resulting from a comparison of teaching listening comprehension to college freshmen by a programmed method as opposed to a conventional approach at the same hours of the day. These results were interpreted according to the (1) two-factor analysis of variance and (2) propor tions of questionnaire responses expressed as percentages.

The statistical analysis of the data involving achievement in 1istening comprehension ability at the hours of 8:00, 10:00, and 1:00 showed a significant difference in the method of instruction employed and the time of day the Instruction was given. Consequently, hypotheses I and II were rejected. The "time of day instruction is received" was found to be significant on the sub-scale of "1istening for immediate recall." "Method of instruction" was found to be significant on the sub-scale of "listening to follow directions." The hypothesis of interaction, III, was accepted, as were the remaining sub-scale hypotheses of IV.

The analysis of the instructional attitude questionnaires completed by the students indicated a slight but seemingly insignificant preference for the programmed method of teaching 1istening comprehension.

Chapter V will present the summary, conclusions, and recommendations of the study based on these findings. 
CHAPTER V

SUMMARY, CONCLUSIONS, AND RECOMMENDATIONS

General Summary of the Investigation

The primary purpose of the present study was to experimentally investigate the effectiveness of teaching listening comprehension to college freshmen by a programmed approach as opposed to a conventional approach at different hours of the day. The subjects in the control group received listening instruction by the conventional methods of lecture, discussion, and assigned supplemental readings. The subjects in the experimental group received listening instruction through the use of the Xerox Effective Listening Program. The writer supplied the students in the experimental group with the response booklets which are required of the Xerox program and secured for each of the instructors the magnetic tapes on which the program is presented.

A secondary purpose of the study was to ascertain the attitude of the subjects toward the method of listening instruction they received. A modified form of the Xerox questionnaire was designed to secure this information.

The subjects of this investigation consisted of freshman students enrolled in Speech 113 at Northeastern State College during the spring semester 1971-1972. The students were randomly assigned by the freshman counselling office to six randomly selected Speech 113 classes of 
which two were offered at 8:00, two at 10:00, and two at 1:00. One class at each of the three time periods was designated the experimental class and received the programmed instructional approach while the three remaining classes were designated the control group and received the conventional method of listening instruction.

The sample for this study included an experimental group of 45 subjects and a control group of 45 subjects; thus, there was a total of 90 students equally distributed in groups of 15 subjects for each of the six classes. Six different instructors were randomly assigned to teach each of the six classes in the study. The duration of the instructional program was two weeks or six class sessions.

The instrument which was used to evaluate the listening comprehension ability of the subjects was the Brown-Carlsen Listening Comprehension Test, Form BM. A Likert-type questionnaire was employed to determine the subjects' attitude toward the method of instruction which they received. Both instruments were adminstered to the subjects upon completion of the instructional unit.

The hypotheses which this investigation was designed to test are as follows:

I. There is no significant difference in the listening achievement scores of freshmen enrolled in Speech 113 at Northeastern State College due to the use of programmed listening instruction as opposed to the conventional method of instruction.

II. There is no significant difference in the listening achievement scores of freshmen enrolled in Speech 113 at Northeastern State College due to the time of day listening instruction is received. 
III. There is no significant difference in the listening achievement. scores of freshmen enrolled in Speech 113 at Northeastern State College due to the interaction of method of listening instruction and time of day instruction is received.

IV. There is no significant difference in the listening achievement scores of freshmen enrolled in Speech 113 at Northeastern State College due to the method of listening instruction received, time of day the instruction is received, or the interaction of method and time of day relative to:

A. Listening for immediate recall.

B. Listening to follow directions.

C. Listening to recognize transitions.

D. Listening to recognize word meanings.

E. Listening for lecture comprehension.

The statistical treatment of the data to test the preceding hypotheses included the following analyses:

1. The two-factor analysis of variance was used to analyze the performance of the groups with respect to the method of instruction, the time of day the instruction was received, and the interaction of method of instruction and time of day instruction was received.

2. The attitude of each group toward the method of instruction received was analyzed by proportions of responses expressed as percentages.

\section{Conclusions of the Study}

The following conclusions seem warranted from the results of the statistical treatment of the data: 
1. The hypothesis of no significant difference in listening achievement due to the method of instruction received was rejected at the .05 level of confidence. There was a significant difference in the achievement scores of the two groups with the group taught by the experimental or programmed method surpassing the performance of those taught by the conventional approach. The average score for the group taught by the programmed approach was 53.91, while the average score for the group taught by the conventional method was 49.84 . For the sample in question, therefore, the Xerox programmed approach to teaching listening comprehension to college freshmen is significantly better than the conventional method and should be considered as a primary means of teaching the skill of listening comprehension.

2. The hypothesis of no significant difference in listening achievement due to the time of day instruction is received was rejected at the .05 level of confidence. There was a significant difference in the achievement scores and the time of day the instruction was received. On the basis of the results of this sample regarding time of instruct. tion, it would appear that the best hour for presenting composite listening material is $1: 00$ rather than $10: 00$, and $8: 00$ is not significantly different from either 10:00 or 1:00.

3. The hypothesis of no significant difference in listening achievement scores due to the interaction of method of instruction and time of day instruction is received was accepted. Thus, interaction was not sufficient to produce any significant effect on the listening scores.

4. In terms of the method of listening instruction employed for specific purposes, the programmed approach is significantly better than 
the conventional method for teaching students in this sample to "follow directions." The mean score of the group taught by the programmed method was 16.55; whereas, the conventionally taught group possessed a mean score of 13.53 .

5. The teaching of "listening for immediate recall" is significantly more effective at 1:00 than 10:00 and the 8:00 time period is not significantly different from the hours of 10:00 or 1:00. The performance for the present sample indicates that those subjects who received listening instruction at 1:00 maintained an average score of 13.26, the 8:00 class secured an average score of 12.23 , while the 10:00 group made the weakest showing with an average score of 11.60 .

6. There is little difference in the attitudes of students with reference to the method of listening instruction they receive. Out of a possible 70 points on the Likert-type attitude questionnaire, the group taught by the programmed method had a mean score of 50.54 ; whereas, the group taught by the conventional approach had a mean . score of 48.74 .

\section{Recommendations for Further Research}

This study, as with much research, has provided some answers to the present problem under consideration. While the outcomes of this study are particularly relevant to the college instructional level, this writer is of the opinion that the findings and conclusions are important to speech communication educators at all academic levels.

In light of the findings of this particular study, sothe implications for additional research in listening comprehension seem implicit. These additional suggested research areas are as follows: 
1. A replication of the present study using variables such as sex, number of speech courses during high school, or whether students have had previous direct training in listening comprehension.

2. An investigation which employs a student's American College Test score in relation to his performance in a programmed or convent: tionally taught unit on listening comprehension.

3. A replication of this study employing a different listening program but the same conventfonal approach.

4. A study which compares the effectiveness of two programmed approaches to teaching listening comprehension.

5. A replication of this study using subjects from different academic grade levels.

6. A replication of the present study in which the instructor is viewed as a variable.

Teaching listening comprehension by programmed instruction may not be the epitome of methodological perfection, but it has proven, in many instances, to be as effective and often more effective than the conventional approach. At this writing, programmed instruction in listening comprehension seems well worth further investigation. 
(1) Rankin, Paul T... "Frequency of Use of Listening," Listening Read-ings, Sam Duker, compiler. New York: The Scarecrow Press, Inc., 1966. pp. 51-62.

(2) Nichols, Ralph G., and Leonard Stevens. Are You Listening? New York: McGraw-Hil1, 1957.

(3) Taylor, Stanford E. Listening: What Research Says to the Teacher, No. 29. Washington, D. C.: National Education Association, 1964.

(4) Hackett, Herbert. "A Nu11 Hypothesis: There is Not Enough Evidence," Education, 75: 149-51, January, 1955.

(5) Bakan, Pau1. "Some Reflections on Listening Behavior," Journa1 of Communication, 6: 108-13, Autumn, 1956.

(6) Barker, Larry L., and Gordom Wiseman. "Research Report No. 57: A Comparative Study of Recall and Recognition Produced Through Programmed Instruction and Lectures on Listening when Time is Constant," (Reviewed by Frank E. X. Dance.) Centra1 States Speech Journal, 16: 140-141, May, 1965.

(7) Binder, F. Eugene, and Edward L. McGlone. "Experimental Evaluation of the Xerox Effective Listening Course," Western Speech Journal, 35: 264-70, Fal1, 1971.

(8) Duker, Sam, and Charles R. Petrie. "What We Know About Listening: Continuation of a Controversey," Journal of Communication, 14: 245-52, December, 1964.

(9) Barbara, Dominick A. The Art of Listening. Springfield, I11.: Charles C. Thomas Co., 1958 .

(10) Fulton, Renee J. "Language Laboratories Develop the Listening Ear," Modern Language Journal, 43: 224-25, May, 1959.

(11) Petrie, Charles R. "An Experimental Evaluation of Two Methods for Improving Listening Comprehension Abilities." Unpublished Doctoral dissertation, Purdue University, Lafayette, Ind., 1961.

(12) Berlo, David K. The Process of Communication. New York: Holt, Rinehart, and Winston, 1970. 
(13) Tucker, W. S. "Science of Listening," 19th Century, 97: 548-57, Apri1, 1925.

(14) Still, Dana Swank. "The Relationship Between Listening Ability and High School Grades." Unpublished Doctoral dissertation, The University of Pittsburgh, Pittsburgh, Pa., 1955.

(15) Nichols, Ralph G., and Thomas Lewis. Listening and Speaking. Dubuque, Iowa: William C. Brown Co., 1954.

(16) Jbnes, Mary Elizabeth. "A Critical Review of Literature on Listening with Special Emphasis on Theoretical Bases for Further Research in Listening." Unpublished Masters thesis, North Carolina State College, Durham, N. C., 1956.

(17) Brown, James I., and Robert G. Carlsen. The Brown-Car1sen Listening Comprehension Test: Manual of Directions. Yonkers, N.Y.: Harcourt, Brace, and Wor1d, Inc., 1955.

(18) Rankin, Paul T. "Listening Ability and its Components," Listening Readings, Sam Duker, compiler. New York: The Scarecrow Press, Inc., 1966. pp. 25-27.

(19) Barbe, Walter B., and Robert M. Meyers. "Developing Listening. Ability in Children," Elementary English. Journal, 31: 82-84, February, 1954.

(20) Barker, Larry L. Listening Behavior. Englewood Cliffs, N. J.: Prentice-Ha11, Inc., 1971

(21) Brown, Donald P. "And Having Ears They Hear Not," National Education Association Journa1, 39: 586-87, November, 1950.

(22) Caffrey, John. "Auding as a Research Problem," California Journal of Educationa1 Research, 4: 155-61, September, 1953.

(23) Rankin, Paul T. "The Measurement of the Ability to Understand Spoken Language." Unpublished Doctoral dissertation, University of Michigan, Ann Arbor, Mich., 1926.

(24) Breiter, Lila R. "Research, In Listening and its Importance to Literature." Unpublished Masters thesis, Brooklyn College, Brooklyn, N.Y., 1957.

(25) Bird, Donald E. "Have You Tried Listening?", Journal of the American Diatetic Assoctation, 30: 225-30, March, 1954 .

(26) Hubbel1, Richard. Television Programming and Production. Third edition. New York: Ho1t, Rinehart, and Winston, Inc., 1956.

(27) Wilt, Miriam E. "Demands on the Listening Skills of Elementary School Students," Listening Readings, Sam Duker, compller. New York: The Scarecrow Press, Inc., 1966. pp. 63-80. 
(28)

(29)

Appel1, Clara, and Morey Appe11. "If We Learn to Listen We'11 Understand," Practical Home Economics, 33: 7-8, December, 1954.

(30) Taylor, Stanford E., Helen Frackenphol, and James L. . Rettee. Grade Leve1 Norms for the Components of the Fundamental Reading Skill. EDL Research and Information Bulletin No. 3. Huntington, N.Y.: Educatipnal Development Laboratories, 1960.

(31) Erickson, C. I., and Irving King. "A Comparison of Visual and Oral Presentation of Lessons in the Case of Pupils from the third to the Ninth Grades," School and Society, 6: 146-48, August, 1917.

(32) Beery, Althea. "Experiences in Listening," Elementary English Journa1, 28: 130-32, March, 1951.

(33) Canfield, George Robert. "A Study of the Effects of Two Types of Instruction on the Listening Comprehension of Fifth Grade Children," Elementary School Journal, 62: 146-51, December, 1961.

(34) Erickson, Allen G. "Can Listening Efficiency be Improved?", Journal of Communication, 4: 128-32, Winter, 1954.

(35)

Bonner, Myrtle Clara Stoddard. "A Critical Analysis of the Relationship of Reading Ability to Listening Ability." Unpublished Doctoral dissertation, Auburn University, Auburn, Ala., 1960.

(36) Haugh, Oscar M. "The Comparative Value of Reading and Listening in the Acquisition of Information and the Changing of Attitudes of Elementary Grade Students," Journal of Educational Research, 45: 489-98, March, 1952.

(37) Hollow, Kevin, Sister M. "Have We Overlooked Listening?", Catholic School Journal, 55: 147-49, May, 1955.

(38) Marsden, W. Ware. "A Study of the Value of Training in Listening to Achievement in Reading." Unpublished Doctoral dissertation, Colorado State College of Education, Greeley, Colo., 1952.

(39) Vineyard, Edwin E., and Robert B. Bailey. "Interrelationships of Reading Ability, Listening Skill, Intelligence, and Scholastic Achievement," Journal of Developmenta1 Reading, 3: 174-78, Spring, 1960.

(40) Hayward, Lillian V. "Listening as an Aid to Learning." Unpublished Masters thesis, New Jersey State Teacher's College, Newark, N.J., 1952. 
(41) Dance, Frank E. X. "Toward a Theory of Human Communication," Human Communication Theory, Frank E. X. Dance, editor. New York: Holt, Rinehart, and Winston, Inc., 1967. pp. 288-309.

(42) Heilman, Arthur. "Listening and the Curriculum," Education, 75: 283-87, January, 1955.

(43) Hampleman, Richard Samuel. "Comparison of Listening and Reading Ability of Fourth and Sixth Grade Pupils," Elementary English Journal, 35: 49-53, January, 1958.

(44) Henmon, V. A. C. "The Relation Between Mode of Presentation and Retention," Psychological Review, 19: 79-96, March, 1912.

(45) Witty, Paul A., and Robert A. Sizemore. "Studies in Listening," Elementary English Journa1, 35: 538-52, December, 1958.

(46) Fessenden, Seth A. "Levels of Listening - A Theory," Education, 75: 288-91, January, 1955.

(47) Bormann, Ernest G., William S. Howe11, Ra1ph G. Nichols, and George L. Shapiro. Interpersonal Communication in the Modern Organization. Englewood Cliffs, N.J.: Prentice-Ha11, Inc., 1969.

(48) Druker, Peter F. The New Society. New York: Harpers, Inc., 1950.

(49) Dover, C. J. "Listening - The Missing Link in Communication," Genera1 Electric Review, 61: 7-10, May, 1958.

(50) Caskey, Clark Charles. "Listen and Lkarn," Supervision, 23: 16-19, July, 1961.

(51) Fischer, Frank E. quoted in Ernest G. Bormann, William S. Howe11, Ralph G. Nichols, and George L. Shapiro. Interpersonal Communication in the Modern Organization. Englewood Cliffs, N. J.: Prentice-Ha11, Inc., 1969.

(52) Jones, H。E. "Experimental Studies of College Training," Archives of Psychology, No.69. New York: Columbia University, 1923.

(53) Irvin, Charles E. "An Analysis of Certain Aspects of a . Listening Training Program Among College Freshmen at Michigan State College," Speech Monographs, 20: 122-23, June 1953.

(54) Applegate, Mauree. Everybody's Business - Our Ch1ldren. Evanston, Ill., Row Peterson Co., 1952.

(55) Anderson, Harold A. "Teaching the Art of Listening," Schoo1 Review, 57: 63-67, February, 1949.

(56) Nicho1s, Ra1ph G. "Listening Instruction in the Secondary Schoo1," Bulletin of the National Association of Secondary School Prin-

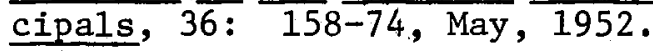


(57) Dow, Clyde Walton, and Charles E. Irvin. "How We Teach . Listening," Bulletin of the National Association of Secondary School Principals, 38: 137-39, January, 1954.

(58) Cashman, Paul Ho "Techniques in Teaching .Listening Skills," Reading in Relation to Mass Media: A Report of the Fourteenth Conference and Course on Reading. Pittsburgh, Pa.: Univer F... sity of Pittsburgh Press, 1958.

(59) Griffin, Kim, and Larry Hannah. "A Study of the Results of an Extremely Short Instructional Unit in Listening." Lawrence, Kansas: University of Kansas, 1960. (Mimeographed.)

(60) Edinger, Lois Virginia. "The Effectiveness of Television Teaching in Developing Pupil Skills of Listening Comprehension and Critical Thinking." Unpublished Doctoral dissertation, University of North Carolina, Chapel Hill, N. C., 1965.

(61) Devine, Thomas G. "The Development and Evaluation of a Series of Recordings for Teaching Certain Critical Listening Abilities." Unpublished Doctoral dissertation, University of North Carolina, Chapel Hil1, N. C., 1965.

(62) Brown, James I. "Can Listening be Taught?", College English, 15: 290-91, February, 1954.

(63) Russe11, David H., and Elizabeth F. Russe11. Listening Aids Through the Grades. New York: Teacher's College, Columbia University, 1959.

(64) Karraker, Mary E. "An Evaluation of the Influence of Interest and 'Set' on Listening Effectiveness in the Basic Communication Class," Speech Monographs, 19: 117-18, June, 1952.

(65) Hirsh, Ira J. The Measurement of Hearing. New York: McGraw-Hill Book Co., 1952。

(66) Canute, Russel1 J. "An Exploratory Evaluation of Certain Aspects of the Listening Program as Part of the Study Skills Course at the University of Wyoming;" Journal of Educational Research, 59: 51-54, October, 1965.

(67) Hollingsworth, Paul Mo "Effectiveness of a Course in Iistening Improvement for Adults," Journa1 of Communication, 16: 189-91, September, 1966.

(68) Howard, George W. "The Art of Listening," Research Development, 14: 30-31, September, 1963.

(69) Keller, Paul W. "Major Findings in Listening in the Past Ten Years," Journal of Communication, 10: 29-38, March, 1960。

(70) Bird, Donald E. "Teaching Listening Comprehension," Journal of Communication, 3: 127-30, November, 1953. 
(71) Adams, Harlen M. "Learning to be Discriminating Listeners," Eng1ish Journa1, 36: 11-15, January, 1947.

(72) Ballenger, Marcus Taylor. "A Study of the Effectiveness of Teaching Listening. Through a Planned Daily Program." Unpublished Masters thesis, Texas Technilogical College, Lubbock, Texas, 1963.

(73) Canfield, George Robert. "Approaches to Listening Improvement," Elementary English Journa1, 35: 525-28, December, 1958.

(74) Brown, Charles T., and Paul W. Keller. "A Modest Proposal for Listening Training,". Quarterly Journal of Speech, 48: 395-99, December, 1962 .

(75) Beery, Althea. "Interrelationships Between Listening and other Language Arts Areas," Elementary English Journal, 31: 164-72, March, 1954 .

(76) Dow, Clyde W. "Integrating the Teaching of Reading and Listening Comprehension, ". Journal of Communication, 8: 118-26, Autumn, 1958 .

(77) Baker, William D. "Listening - A Functional Part of Composition," Journal of Communication, 6: . 174-78, Winter, 1956.

(78) Francis, Sister Clara. "A Frontal Attack on the First Language Art," Catholic Educator, 34: 799-800, Apri1, 1964.

(79) Elliff, Gertrude. "A Direct Approach to the Study of Listening," English Journal, 46: 20-27, January, 1957.

(80) Gallant, Ruth. "The Improvement of Listening Comprehension Skills at the College Level.'... Unpublished Masters thesis, Miami University, Oxford, Ohio, 1959.

(81) Baker, E1don E. "Programed Instruction Defined," Speech Teacher, 18: 262, November, 1969.

(82) King, Thomas R. "Programmed Textbooks in Communication," Journal of Communication, 55-61, March, 1967.

(83). Erway, Ella Anderson. "The Development of Programmed Materials for Teaching Cognitive . Listening. Skills . in a ... Speech Laboratory. in the Beginning . Speech Course at Hunter College, New York." Unpublished Doctoral dissertation, Columbia University, New York, 1966.

(84) Northeastern State College. Northeastern State College Catalog: 1971-72. Tahlaquah, Okla.: Northeastern State College Press, 1971 . 
(85) Bruning, James L., and..B. L. Kintz. Computational Handbook of Statistics. Glenview, I11.: Scott, Foresman, and Co., 1968.

(86) Kerlinger, Fred N. Foundations of Behavioral Research... New York: Holt, Rinehart, and Winston, Inc., 1964.

(87) Xerox Corporation, Effective Listening: A Programmed Approach. New York: Xerox Corporation, 1967.

(88) Kelly, Charles M. "An Investigation of the Construct Validity of Two Commercially Published Listening Tests," Speech Monographs, 32: 139-43, June, 1965.

(89) Buros, K. 0. (ed.). The Fifth Mental Measurements Yearbook. Highland Park, N. J.: Gryphon Press, 1959.

(90) Runyon, Richard P., and Audrey Haber. Fundamentals of Behavioral Statistics. Reading, Mass.: Addison-Wesley Publishing Company, Inc., 1967. 
APPENDIX

INSTRUCTIONAL ATTITUDE QUESTIONNAIRE 
Please respond to each of the following statements by placing an " $X$ " in the category that most nearly expresses your feelings on each of the individua1 statements. PLEASE RESPOND TO ALL STATEMENTS.

\section{Sample statement}

Listening is important in communication.

$$
\begin{aligned}
& \frac{1 / 1 / 1 / \mathrm{X} /}{\mathrm{SD}} \\
& \mathrm{SD}=\text { Strongly Disagree } \\
& \mathrm{D}=\mathrm{Disagree} \\
& \mathrm{N}=\text { Neutral } \\
& \mathrm{A}=\text { Agree } \\
& \mathrm{SA}=\text { Strongly Agree }
\end{aligned}
$$

1. Many statements in the course might have been heard in the everyday world. I feel that the instruction will enable me to Iisten more effectively to such statements.

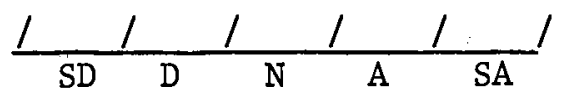

2. I feel that the teaching level of the instruction was too easy.

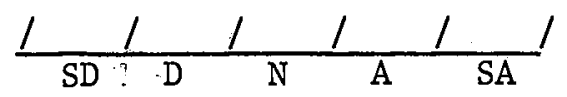

3. I felt that I listened more effectively toward the end of the instruction than at the beginning.

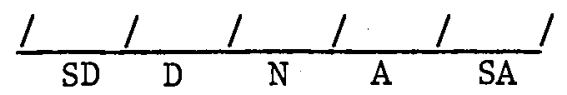

4. I would have preferred a different method of instruction.

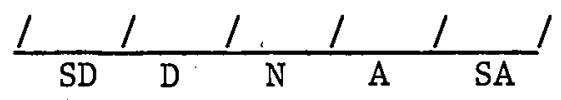

5. Before receiving this instruction I was able to adequately summarize spoken remarks as the speaker proceedêd.

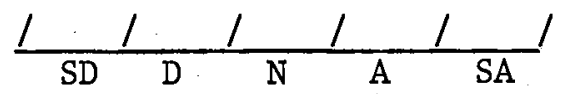

6. I feel that the instruction I received will provide improvement in listening to statements centering around a particular product or course of action.

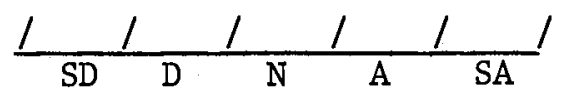


7. I feel that the teaching level of the instruction was too difficult.

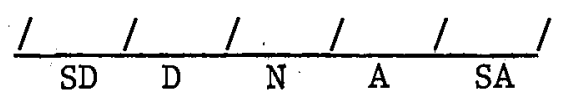

8. I feel that I better appreciate the importance of listening skills as a result of the instruction.

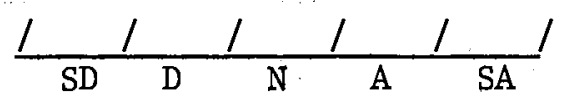

9. I feel that the instruction I received will provide improvement in 1istening to a11 statements.

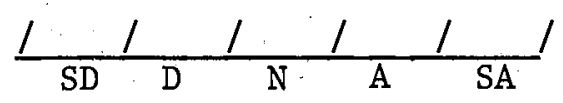

10. After receiving this instruction I was able to summarize a speaker's remarks as he proceeded.

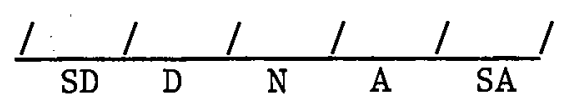

11. I feel that this method of instruction is well-suited for teaching listening skills.

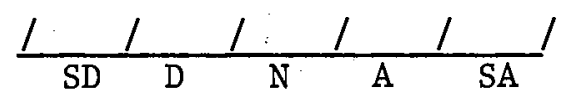

12. I feel that the organization of my spoken statements will be more effective as a result of this instruction.

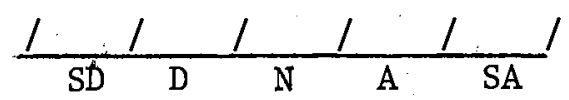

13. In general I feel that this instruction has improved my listening skills.

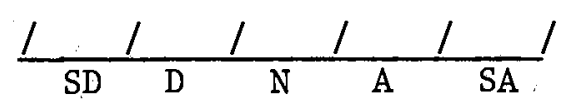

14. I feel that the material was presented in an interesting manner.

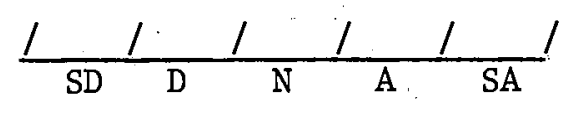

15. Was there anything about the method of instruction that you particularly liked?

16. Was there anything about the instruction that you particularly disliked? 
VITA

Thomas L. Cottrill

Candidate for the Degree of

Doctor of Education

Thesis: A COMPARISON OF TWO METHODS OF TEACHING LISTENING COMPREHENSION TO COLLEGE FRESHMEN

Major Field: Higher Education

Biographical:

Personal Data: Born on August 9, 1943, in Tillimook, Oregon, the son of $\mathrm{Mr}$. and Mrs. Thomas E. Cottrill.

Education: Graduated from Inola High School,.. Inola, Oklahoma, in 1961; received the Bachelor of Arts degree with major in English and a minor In speech from Northeastern State College, Tahlequah, Oklahoma, in 1965; received the Master of Teaching degree with a major in speech-education from Northeastern State College, Tahlequah, Oklahoma, in 1967; completed the requirements for the Doctor of Education degree at Oklahoma State University in July, 1972.

Professional Experience: Engfish teacher at Broken Arrow High School, Broken Arrow, Oklahoma, 1965 through 1966; graduate assistant in the department of speech at Northeastern State College, Tahlequah, Oklahoma, 1966 through 1967; assistant professor of speech at Northeastern State College, Tahlequah, Oklahoma, from 1967 until present. 